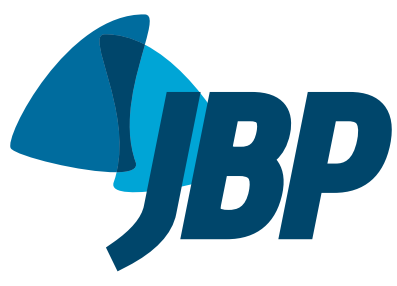

1. Programa de Pós-Graduação em Ciências Médicas, Universidade Federal de Santa Catarina - UFSC Florianópolis (SC) Brasil.

2. Divisão de Pneumologia, Instituto do Coração - InCor - Hospital das Clínicas, Faculdade de Medicina, Universidade de São Paulo, São Paulo (SP) Brasil.

3. Faculdade de Ciências Médicas, Santa Casa de Misericórdia de São Paulo, São Paulo (SP) Brasil.

4. Universidade Federal de Ciências da Saúde de Porto Alegre - UFCSPA Porto Alegre (RS) Brasil.

5. Santa Casa de Misericórdia de Porto Alegre, Porto Alegre (RS) Brasil.

6. Universidade Estadual de Londrina UEL - Londrina (PR) Brasil.

7. Pontifícia Universidade Católica do Paraná - PUCPR - Londrina (PR) Brasil.

8. Universidade Federal do Rio de Janeiro - UFRJ - Rio de Janeiro (RJ), Brasil.

9. Universidade Federal da Bahia - UFBA Salvador (BA) Brasil.

10. Fundação ProAR, Salvador (BA) Brasil.

11. Escola Paulista de Medicina Universidade Federal de São Paulo UNIFESP - São Paulo (SP) Brasil.

12. Escola de Medicina, Pontifícia Universidade Católica do Rio Grande do Sul - PUCRS - Porto Alegre (RS), Brasil.

13. Faculdade de Medicina de Ribeirão Preto, Universidade de São Paulo, Ribeirão Preto (SP) Brasil.

14. Pontifícia Universidade Católica de Minas Gerais, Belo Horizonte (MG), Brasil.

15. Hospital Júlia Kubitschek Belo Horizonte (MG), Brasil.

16. Universidade Federal de Pernambuco - UFPE - Recife (PE) Brasil.

17. Hospital das Clínicas, Universidade Federal de Minas Gerais - UFMG Belo Horizonte (MG) Brasil

18. Faculdade de Medicina, Universidade Federal de Goiás - UFG - Goiânia (GO) Brasil.

19. Universidade Federal da Paraíba UFPB - João Pessoa (PB) Brasil.

20. Hospital Dia do Pulmão Blumenau (SC) Brasil.

21. Instituto da Criança, Faculdade de Medicina, Universidade de São Paulo São Paulo (SP) Brasil.

22. Hospital Moinhos de Vento Porto Alegre (RS) Brasil.

Submitted: 4 September 2019 Accepted: 7 December 2019

Study carried out under the auspices of the Sociedade Brasileira de Pneumologia e Tisiologia, Brasília (DF) Brasi.

\section{Brazilian Thoracic Association recommendations for the management of asthma}

Marcia Margaret Menezes Pizzichini' ${ }^{1}$, Regina Maria de Carvalho-Pinto ${ }^{2}$ (iD José Eduardo Delfini Cançado ${ }^{3}$ (D), Adalberto Sperb Rubin, ${ }^{4,5}$ (D), Alcindo Cerci Neto ${ }^{6,7} \mathbb{D}^{-}$, Alexandre Pinto Cardoso ${ }^{8}(\mathbb{D}$, Alvaro Augusto Cruz $\mathrm{Z}^{9,10}$ (i), Ana Luisa Godoy Fernandes ${ }^{11}$ (i), Daniella Cavalet Blanco ${ }^{12}$ (i), Elcio Oliveira Vianna ${ }^{13}$ (D), Gediel Cordeiro Junior ${ }^{14,15}$ (D), José Angelo Rizzo ${ }^{16}$ (i), Leandro Genehr Fritscher ${ }^{12}$ (D), Lilian Serrasqueiro Ballini Caetano ${ }^{11}$ (i), Luiz Fernando Ferreira Pereira' ${ }^{17}$, Marcelo Fouad Rabahi ${ }^{18}$ (i), Maria Alenita de Oliveira ${ }^{19}(\mathbb{D})$, Marina Andrade Lima ${ }^{20}(\mathbb{D}$, Marina Buarque de Almeida ${ }^{21}\left(\mathbb{D}\right.$, Rafael Stelmach ${ }^{2}$ (D), Paulo Márcio Pitrez ${ }^{22(\mathbb{D})}$ Alberto Cukier' ${ }^{2}$ (I)

\section{ABSTRACT}

The pharmacological management of asthma has changed considerably in recent decades, as it has come to be understood that it is a complex, heterogeneous disease with different phenotypes and endotypes. It is now clear that the goal of asthma treatment should be to achieve and maintain control of the disease, as well as to minimize the risks (of exacerbations, disease instability, accelerated loss of lung function, and adverse treatment effects). That requires an approach that is personalized in terms of the pharmacological treatment, patient education, written action plan, training in correct inhaler use, and review of the inhaler technique at each office visit. A panel of 22 pulmonologists was invited to perform a critical review of recent evidence of pharmacological treatment of asthma and to prepare this set of recommendations, a treatment guide tailored to use in Brazil. The topics or questions related to the most significant changes in concepts, and consequently in the management of asthma in clinical practice, were chosen by a panel of experts. To formulate these recommendations, we asked each expert to perform a critical review of a topic or to respond to a question, on the basis of evidence in the literature. In a second phase, three experts discussed and structured all texts submitted by the others. That was followed by a third phase, in which all of the experts reviewed and discussed each recommendation. These recommendations, which are intended for physicians involved in the treatment of asthma, apply to asthma patients of all ages.

Keywords: Asthma/therapy; Asthma/drug therapy; Asthma/prevention \& control; Practice guideline.

\section{INTRODUCTION}

The pharmacological management of asthma has changed considerably in recent decades, based on the understanding that asthma is a complex and heterogeneous disease, with different phenotypes and endotypes. This knowledge has changed the strategies for managing the disease, making way for the emergence of new drugs to control asthma. Several recent international guidelines and recommendations summarize the criteria for the treatment of asthma in steps, allowing an overall view of the incremental increases in the control treatment as the severity of asthma increases. ${ }^{(1-6)}$ Despite these advances, the level of control of the disease remains low, with high morbidity, irrespective of the country studied. $(7,8)$

The heterogeneity of asthma is evidenced by the various phenotypes (observable characteristics of an individual) and endotypes (molecular or pathophysiological mechanism underlying the phenotype) of the disease. Among the more frequently used inflammatory phenotypes are eosinophilic asthma, noneosinophilic asthma,

Correspondence to:

Marcia M. M. Pizzichini. Programa de Pós-Graduação em Ciências Médicas, Hospital Universitário, Universidade Federal de Santa Catarina, Campus Universitário, Trindade, CEP 88040-970, Florianópolis, SC, Brasil.

Tel./Fax: 5548 3234-7711. E-mail: marcia.pizzichini6@gmail.com

Financial support: None. 
allergic asthma, and nonallergic asthma. The various endotypes include high and low Th2-driven inflammation, designated the Th2-high and Th2-low subtypes, respectively. ${ }^{(9)}$ Asthma patients with the Th2-high subtype usually present early-onset asthma that is more severe, accompanied by atopy/IgE and airway and systemic eosinophilia. Asthma patients with the Th2-high subtype tend to be responsive to corticosteroids and drugs that inhibit Th2-driven inflammation. ${ }^{(10)}$ In contrast, those with the Th2-low subtype generally have late-onset asthma, with no airway or systemic eosinophilia, and show reduced responsiveness to corticosteroids. Patients with the Th2-low subtype also do not respond to the drugs that inhibit Th2-driven inflammation. ${ }^{(9)}$

Evidence from studies of induced sputum samples show that the majority of asthma patients have a concordant type of disease; that is, as the airway inflammation increases, the symptoms increase, and as the airway inflammation decreases the symptoms decrease. ${ }^{(11)}$ Therefore, for the great majority of asthma patients, the treatment may be guided by the symptoms, the dose of anti-inflammatory medication being increased or decreased to achieve and maintain control of the disease.

The present recommendations apply to adults and children with asthma. They are intended for clinicians involved in the treatment of asthma in clinical practice, except for severe asthma, which will be discussed in greater depth in another set of recommendations. With the objective of critically summarizing recent evidence of the pharmacological treatment of asthma, we brought together 22 experts from Brazil to draw up the present recommendations, a guide for asthma treatment adapted for use in Brazil. The themes were selected by the panel of experts, who chose topics or questions relating to the most significant changes in the concepts and, consequently, in the management of asthma in clinical practice. Each expert was invited to provide a critical review of a topic or to respond to a question from those recommendations. In a second phase, three experts discussed and structured all of the texts received from the others. In a third phase, all of the experts reviewed and discussed the present recommendations.

\section{Concept}

Asthma is a heterogeneous disease, usually characterized by chronic airway inflammation. It is defined by a history of respiratory symptoms, such as wheezing, dyspnea, retrosternal chest pressure, and cough, all of which vary longitudinally and in intensity, accompanied by variable airflow limitation. ${ }^{(1)}$

\section{Epidemiology of asthma in Brazil}

The prevalence of asthma symptoms among adolescents in Brazil, according to international studies, was $20 \%$-one of the highest in the world-in 2007.(12) A study by the World Health Organization indicated that, among adults $18-45$ years of age in Brazil, $23 \%$ had experienced symptoms of asthma within the previous year, ${ }^{(13)}$ although only $12 \%$ had previously been diagnosed with asthma. A study conducted in 2012 , involving 109,104 adolescents, also found that $23 \%$ had asthma symptoms and $12 \%$ had previously been diagnosed with asthma. ${ }^{(14)}$

In 2013 , there were 129,728 hospitalizations and 2,047 deaths due to asthma in Brazil. The rates of asthma-related hospitalization and mortality are decreasing in most regions, in parallel with increased access to treatment. ${ }^{(15)}$ Uncontrolled asthma generates high costs for the health care system as well as for families. ${ }^{(16)}$ In cases of severe asthma, it is estimated that this corresponds to more than a quarter of the family income among users of the Brazilian Sistema Único de Saúde (SUS, Unified Health Care System), ${ }^{(16,17)}$ although the cost could be reduced significantly with the adequate control of the disease. ${ }^{(18)}$ However, a nationwide survey found that only $12.3 \%$ of asthma patients had well-controlled asthma. ${ }^{(19)}$

Various interventions at the municipal level have been shown to be effective in controlling asthma symptoms, as well as in reducing the number of exacerbations and hospitalizations. ${ }^{(20,21)}$ However, the problems with underdiagnosis and lack of training among primary health care professionals ${ }^{(22)}$ require action. A nationwide experiment in training Family Health Program teams in the treatment of chronic respiratory diseases through collaborative care, with the support of experts, has been successful and could be expanded.(23)

\section{Difference between asthma control and severity}

The concept of asthma control comprises two distinct domains $^{(1,24)}$ : the control of current clinical limitations, such as minimal symptoms during the day, the absence of symptoms at night, a reduced need for rescue medication, and no limitation of physical activities; and the reduction of future risks, such as exacerbations, accelerated loss of lung function, and adverse treatment effects. On the basis of those parameters, asthma can be classified as controlled, partially controlled, or uncontrolled (Chart 1). ${ }^{(1,25,26)}$ The degree of control is typically evaluated by considering the last 4 weeks.

Asthma education and the judicious management of medication therapy are key to controlling the disease. The periodic assessment of asthma control is an important dynamic marker of the severity of the disease and the main parameter for determining the need to adjust the treatment plan.

Currently, in addition to the asthma control questionnaire created by the Global Initiative for Asthma (GINA), (1) other tools have been culturally adapted for use in Brazil, including the Asthma Control Questionnaire ${ }^{(25)}$ and the Asthma Control Test. ${ }^{(26)}$ The advantage of using these last two tools is their numerical evaluation (Chart 1 ), which facilitates understanding of the level of asthma control by the patient and the physician. Although spirometry is not part of either 
Chart 1. Definition of asthma control by different instruments.

\begin{tabular}{|c|c|c|c|}
\hline Instrument/items & Controlled asthma & $\begin{array}{l}\text { Partially controlled } \\
\text { asthma }\end{array}$ & Uncontrolled asthma \\
\hline $\begin{array}{l}\text { Diurnal symptoms }>2 \text { times per week } \\
\text { Nocturnal awakenings due to asthma } \\
\text { Rescue medication }>2 \text { times per week } \\
\text { Limitation of activities due to asthma }\end{array}$ & None & $1-2$ items & 3-4 items \\
\hline ACQ-7 a & & Score & \\
\hline $\begin{array}{l}\text { Number of nocturnal awakenings } \\
\text { Intensity of symptoms } \\
\text { Limitation of activities due to asthma } \\
\text { Intensity of dyspnea } \\
\text { Wheezing (how long) } \\
\text { Rescue medication } \\
\text { Pre-bronchodilator FEV }\end{array}$ & $\leq 0.75$ & 0.75 to $<1.5$ & $>1.5$ \\
\hline ACT & & Score & \\
\hline $\begin{array}{l}\text { Limitation of activities due to asthma } \\
\text { Dyspnea } \\
\text { Nocturnal awakenings due to asthma } \\
\text { Rescue medication } \\
\text { Self-assessment of asthma control }\end{array}$ & $\geq 20$ & $15-19$ & $\leq 15$ \\
\hline
\end{tabular}

the GINA questionnaire for the evaluation of asthma control $^{(1)}$ or the Asthma Control Test, (26) it should be performed, if available, every 3-6 months in order to estimate the future risk of exacerbations and accelerated loss of lung function.

Although the concept of asthma control expresses the degree with which the manifestations of asthma are suppressed by treatment, varying over periods of days or weeks, the concept of asthma severity refers to the quantity of medication needed to attain control, reflecting a characteristic of the disease that can change slowly over time. ${ }^{(1)}$

\section{Factors that influence asthma control}

The factors that influence the response to asthma treatment include the following: misdiagnosis; lack of adherence; use of medications that can decrease the response to treatment (nonsteroidal anti-inflammatory drugs and beta-blockers); indoor exposure (e.g., to dust or smoke); occupational exposure; smoking; and other comorbidities. Therefore, it is recommended that the factors that influence asthma control be checked prior to any modification in the treatment of patients with asthma, partially controlled or not controlled. ${ }^{(1)}$

\section{Adherence to treatment}

The main cause of poor asthma control is low adherence to treatment due to voluntary factors (fears and myths about the treatment) or involuntary factors (lack of access to treatment or difficulty in using an inhaler). ${ }^{(1)}$ At present, adherence to asthma treatment remains low. ${ }^{(19)}$ Difficulty in detecting nonadherence is the main obstacle to addressing this problem. A nationwide survey revealed that only $32 \%$ of the asthma patients in Brazil are compliant with treatment. ${ }^{(19)}$ Although assessments through medical history, counting medications, verifying pharmacy records, detecting side effects, and using other methods at our disposal have not proven sufficient, the must nevertheless be employed. There is growing interest in the development of more accurate methods of measuring adherence to treatment, and the use of electronic devices could be an option. $(27,28)$

\section{Smoking}

Exposure to second-hand smoke, in children and adults, increases the risk of exacerbations and impairs asthma control. In addition, smoking increases the severity of asthma, hampers its control, accelerates the loss of lung function, and decreases the responsiveness to inhaled corticosteroids (ICS). ${ }^{(1,29)}$ Smokers with asthma have an increased risk of hospitalization and severe exacerbation.

\section{Environmental and occupational exposure}

Environmental exposure (e.g., to dust and pollutants), whether at home (from biomass burning, mites, cockroach allergens, animal dander, etc.) or at work (from latex, low-molecular-weight agents, and cleaning materials) are important factors associated with the difficulty of asthma control. In addition, occupational exposure may be the cause of asthma (occupational asthma). ${ }^{(30)}$

That is why it is important to investigate each patient in relation to their associated exposures and, when identified, these should be eliminated or minimized, 
if possible (especially for patients with occupational asthma).

\section{Use of other drugs that may impair asthma control}

Aspirin and other nonsteroidal anti-inflammatory drugs can cause severe asthma exacerbation in sensitized individuals, and beta-blockers (in oral or ophthalmic formulations) may cause bronchospasm. Therefore, the decision about their use should be considered individually, weighing the risks and benefits. ${ }^{(1)}$

\section{Comorbidities}

A thorough investigation of all of the factors associated with difficult-to-control asthma in every asthma patient is unnecessary. ${ }^{(31)}$ However, in cases of difficult-tocontrol asthma, which affects $17.4 \%$ of all adult asthma patients and $74.1 \%$ of those in treatment classified as GINA step 4 or ${ }^{\left({ }^{(32)}\right.}$ a systematic investigation must be performed to identify, minimize, or eliminate comorbidities (such as gastroesophageal reflux, obesity, vocal cord dysfunction, chronic rhinosinusitis, nasal polyposis, anxiety, depression, sleep apnea, COPD, allergic bronchopulmonary aspergillosis, and bronchiectasis) and to avoid asthma being caused or worsened by occupational exposure, among other things that can impair the disease control.

\section{THE PREFERRED TREATMENT FOR ASTHMA CONTROL}

The treatment of asthma seeks to achieve or maintain the current level of control of the disease and to prevent future risks (exacerbations, instability of the disease, accelerated loss of lung function, and adverse effects of treatment).(1) In addition to pharmacological treatment, this requires a personalized approach including patient education, a written action plan, training in the use of the inhaler, and reviewing the inhalation technique at each visit.

The basis of pharmacological treatment for asthma is the use of an ICS, with or without a long-acting $\beta_{2}$ agonist (LABA). These medications are available for use in Brazil in a variety of dosages and inhaler devices (Table 1). In clinical practice, choosing the medication, the inhaler, and its dosage should be based on the assessment of symptom control, patient characteristics (risk factors, ability to use the inhaler in a correct manner, and cost), the preference of the patient for the inhaler device, clinical judgment, and the availability of the medication. Therefore, there is no single medication, dose, or inhaler that applies without distinction to all patients with asthma.

In the GINA, asthma control treatment is divided into steps 1 through $5^{(1)}$, in which the dose of ICS is progressively increased or other controller medications are added (Figures 1-3). The recommended controller medications at the different treatment steps are described below.

\section{ICS}

The efficacy of the different types of ICS varies depending on their pharmacokinetics and pharmacodynamics, as well as on pulmonary deposition and adherence to treatment. . $^{(1,33,34)}$ The equivalence of the different types of ICS, divided into low, medium, and high dosages, is described in Table $2 \cdot(1,3,5,6,24)$ The assessment of the response to treatment with ICS should be made through the combination of clinical and functional parameters. After obtaining and maintaining asthma control for an extended time (not less than 3 months), the ICS dose can be reduced to a minimum, with the aim of using the lowest possible dose to maintain asthma control.

The use of an ICS can cause local adverse effects, such as throat irritation, dysphonia, and candidiasis. ${ }^{(1,35)}$ The use of a pressurized, metered-dose inhaler with a spacer decreases the risk of adverse effects, as does oral hygiene after inhalation of each dose of ICS. The use of high doses of ICS for prolonged periods increases the risk of systemic adverse effects, such as reduction of bone mineral density, respiratory infections (including tuberculosis), cataracts, glaucoma, and suppression of the hypothalamic-pituitary-adrenal axis. ${ }^{(1,36-39)}$

\section{ICS-LABA combination}

Combining an ICS with a LABA or an ultra-LABA is the preferred control treatment in GINA steps 3 and $4^{(1)}$; that is, when treatment with ICS alone is not sufficient to achieve and maintain control of the disease. The evidence for using the ICS-LABA combination as the preferred control therapy in GINA steps $3-5$ is robust. ${ }^{(40-47)}$

In its most recent edition, the GINA expanded upon that recommendation, suggesting the combination of low dose ICS and as-needed formoterol as the preferred asthma control treatment in step 1. In GINA step 2, two options are given ${ }^{(1)}$ : continuous low dose ICS therapy or an ICS+as-needed formoterol.

In GINA step 1, the recommendation for the use of ICS+formoterol for asthma patients $>12$ years of age is based on indirect evidence from other studies employing that combination in patients with mild asthma. ${ }^{(48)}$ The current GINA ${ }^{(1)}$ recommendations for step 2 treatment are based on two large, controlled, double-blind randomized clinical trials (RCTs) of non-inferiority that assessed the use of as-needed low-dose budesonide+formoterol $(200 \mu \mathrm{g}$ and $6 \mu \mathrm{g}$, respectively) versus fixed-dose ICS, for a period of 52 weeks, in patients with mild asthma. ${ }^{(4,50)}$ The results show that a fixed-dose ICS was better in the control of symptoms; however, for the reduction of exacerbations, the as-needed budesonide+formoterol option was not inferior and was superior to the use of a short-acting $\beta_{2}$ agonist (SABA) alone. More recently, these results were confirmed in a pragmatic, open-label study. ${ }^{(51)}$

The rationale for using ICS+LABA is based on strong evidence that this combination is more effective in controlling the symptoms of asthma, reducing 
Table 1. Inhaled asthma controller medications available in Brazil. ${ }^{a}$

\begin{tabular}{|c|c|c|c|c|}
\hline \multicolumn{5}{|c|}{ Inhaled corticosteroid alone } \\
\hline Medications & Inhaler (number of doses) & Trade name ${ }^{\circledast}$ & Dose administered & $\begin{array}{l}\text { Age approved } \\
\text { in the insert }\end{array}$ \\
\hline \multirow[t]{2}{*}{$\mathrm{BDP}(\mathrm{HFA})^{\mathrm{b}}$} & \multirow[t]{2}{*}{ pMDI (200) } & \multirow[t]{2}{*}{ Clenil spray } & $50 \mu \mathrm{g}$ & $\begin{array}{l}\text { Children and } \\
\text { adults }\end{array}$ \\
\hline & & & 200 or $250 \mu \mathrm{g}$ & Only adults \\
\hline BDP & DPI capsules $(60)$ & Miflasona & 200 or $400 \mu \mathrm{g}$ & $\begin{array}{l}\text { Children and } \\
\text { adults }\end{array}$ \\
\hline \multirow{2}{*}{ BUD } & DPI capsules (15 and 60$)$ & Busonide caps & \multirow{2}{*}{200 or $400 \mu \mathrm{g}$} & \multirow{2}{*}{$\geq 6$ years } \\
\hline & Aerolizer (30 and 60) & Miflonide & & \\
\hline FTC & Diskus $(60)$ & Flixotide & 50 or $250 \mu g$ & $\geq 4$ years \\
\hline \multirow{2}{*}{ FTC (HFA) } & \multirow{2}{*}{ pMDI (60 or 120$)$} & \multirow{2}{*}{ Flixotide spray } & $50 \mu \mathrm{g}$ & $\geq 1$ year \\
\hline & & & $250 \mu \mathrm{g}$ & $\geq 4$ years \\
\hline MOM & DPI - Capsules (60) & Oximax & 200 or $400 \mu \mathrm{g}$ & $\geq 12$ years \\
\hline \multicolumn{5}{|c|}{ Inhaled corticosteroids in combination with LABA } \\
\hline Medications & Inhaler (number of doses) & Trade name ${ }^{\circledast}$ & Dose administered & $\begin{array}{c}\text { Age approved } \\
\text { in the insert }\end{array}$ \\
\hline \multirow{2}{*}{ FORM + BUD - } & \multirow{2}{*}{$\begin{array}{l}\text { Aerocaps single capsule } \\
\qquad(15 / 30 / 60)\end{array}$} & \multirow{2}{*}{ Alenia } & $6 / 100 \mu \mathrm{g}$ or $6 / 200 \mu \mathrm{g}$ & $\geq 4$ years \\
\hline & & & $12 / 400 \mu \mathrm{g}$ & $\geq 6$ years \\
\hline FORM + BUD - & $\begin{array}{l}\text { Aerolizer separate capsules } \\
\qquad(60)\end{array}$ & Foraseq & $6 / 100 \mu \mathrm{g}$ or $6 / 200 \mu \mathrm{g}$ & $\geq 12$ years \\
\hline \multirow{2}{*}{ FORM + BUD - } & \multirow{2}{*}{ Turbuhaler (60) } & \multirow{2}{*}{$\begin{array}{l}\text { Symbicort } \\
\text { Turbuhaler }\end{array}$} & $6 / 100 \mu \mathrm{g}$ or $6 / 200 \mu \mathrm{g}$ & $\geq 4$ years \\
\hline & & & $12 / 400 \mu \mathrm{g}$ & $\geq 12$ years \\
\hline \multirow{2}{*}{ FORM + BUD (HFA) - } & \multirow{2}{*}{ pMDI (120) } & \multirow{2}{*}{$\begin{array}{c}\text { Symbicort; Vannair } \\
\text { spray }\end{array}$} & $6 / 100 \mu \mathrm{g}$ & $\geq 6$ years \\
\hline & & & $6 / 200 \mu g$ & $\geq 12$ years \\
\hline$F O R M+B D P(H F A)^{b}$ & pMDI (120) & Fostair spray & $6 / 100 \mu g$ & $\geq 18$ years \\
\hline$F O R M+B D P^{b}$ & Next (120) & Fostair DPI & $6 / 100 \mu g$ & $\geq 18$ years \\
\hline$F O R M+F P$ & CDM-Haller single capsule $(60)$ & Lugano & $12 / 250 \mu \mathrm{g}$ & $\geq 12$ years \\
\hline \multirow{2}{*}{ SALM + FP (HFA) } & \multirow{2}{*}{ Diskus (60) } & \multirow{2}{*}{ Seretide Diskus } & $50 / 100 \mu \mathrm{g}$ & $\geq 4$ years \\
\hline & & & $50 / 200 \mu \mathrm{g}$ or $50 / 500 \mu \mathrm{g}$ & $\geq 12$ years \\
\hline \multirow{2}{*}{ SALM + FP (HFA) } & \multirow{2}{*}{ pMDI (120) } & \multirow{2}{*}{ Seretide spray } & $25 / 50 \mu \mathrm{g}$ & $\geq 4$ years \\
\hline & & & $25 / 125 \mu \mathrm{g}$ or $25 / 250 \mu \mathrm{g}$ & $\geq 12$ years \\
\hline
\end{tabular}

Medications $\quad$ Inhaler (number of doses) $\quad$ Trade name $^{\circledR} \quad$ Dose administered $\quad$ Age approved

\begin{tabular}{|c|c|c|c|c|}
\hline & & & & in the insert \\
\hline \multirow{2}{*}{ BDP (HFA) } & $\mathrm{pMDI}(200)$ & $\begin{array}{c}\text { Clenil Compositum } \\
\text { HFA }\end{array}$ & $50 / 100 \mu \mathrm{g}$ & $\geq 6$ years \\
\hline & Solution for nebulization & Clenil Compositum A & $400 \mu \mathrm{g} / \mathrm{mL}$ and $800 \mu \mathrm{g} / \mathrm{mL}$ & $\begin{array}{c}\text { Children and } \\
\text { adults }\end{array}$ \\
\hline \multicolumn{5}{|c|}{ Inhaled corticosteroid in combination with an ultra-LABA } \\
\hline Medications & Inhaler (number of doses) & Trade name ${ }^{\circledR}$ & Dose administered & $\begin{array}{l}\text { Age approved } \\
\text { in the insert }\end{array}$ \\
\hline $\mathrm{FF}+\mathrm{VI}$ & Ellipta (30) & Relvar & $100 / 25 \mu \mathrm{g}$ or $200 / 25 \mu \mathrm{g}$ & $\geq 12$ years \\
\hline \multicolumn{5}{|c|}{ LAMA } \\
\hline Medications & Inhaler (number of doses) & Trade name ${ }^{\circledast}$ & Dose administered & $\begin{array}{l}\text { Age approved } \\
\text { in the insert }\end{array}$ \\
\hline Tiotropium (AC) & Respimat (60) & Spiriva & $2.5 \mu \mathrm{g}$ & $\geq 6$ years \\
\hline
\end{tabular}

BDP: beclomethasone dipropionate; HFA: hydrofluoroalkane; pMDI: pressurized metered-dose inhaler; DPI: dry powder inhaler; BUD: budesonide; FP: fluticasone propionate; MOM: mometasone furoate; LABA: long-acting $\beta_{2}$ agonist; FORM: formoterol fumarate; SALM: salmeterol xinafoate; SABA: short-acting $\beta_{2}$ agonist; FF: fluticasone furoate; VI: vilanterol; LAMA: long-acting muscarinic antagonist; and AC: aerosol "cloud". aThe recommendations for each dose of medication were taken from the package inserts of medications approved by the Brazilian National Health Oversight Agency. The equivalence of medications in this table and ages with evidence for clinical use should be verified. 'Extra fine particles.

exacerbations, and slowing the loss of lung function after exacerbations than is an ICS alone. ${ }^{(40-47,52)}$ In addition, there is evidence showing that the ICS-LABA combination has a synergistic effect, which allows more anti-inflammatory efficacy with a smaller dose of ICS and, consequently, fewer adverse effects. ${ }^{(53)}$

Two recent studies involving a large number of adults and adolescents with asthma using the ICS-LABA 


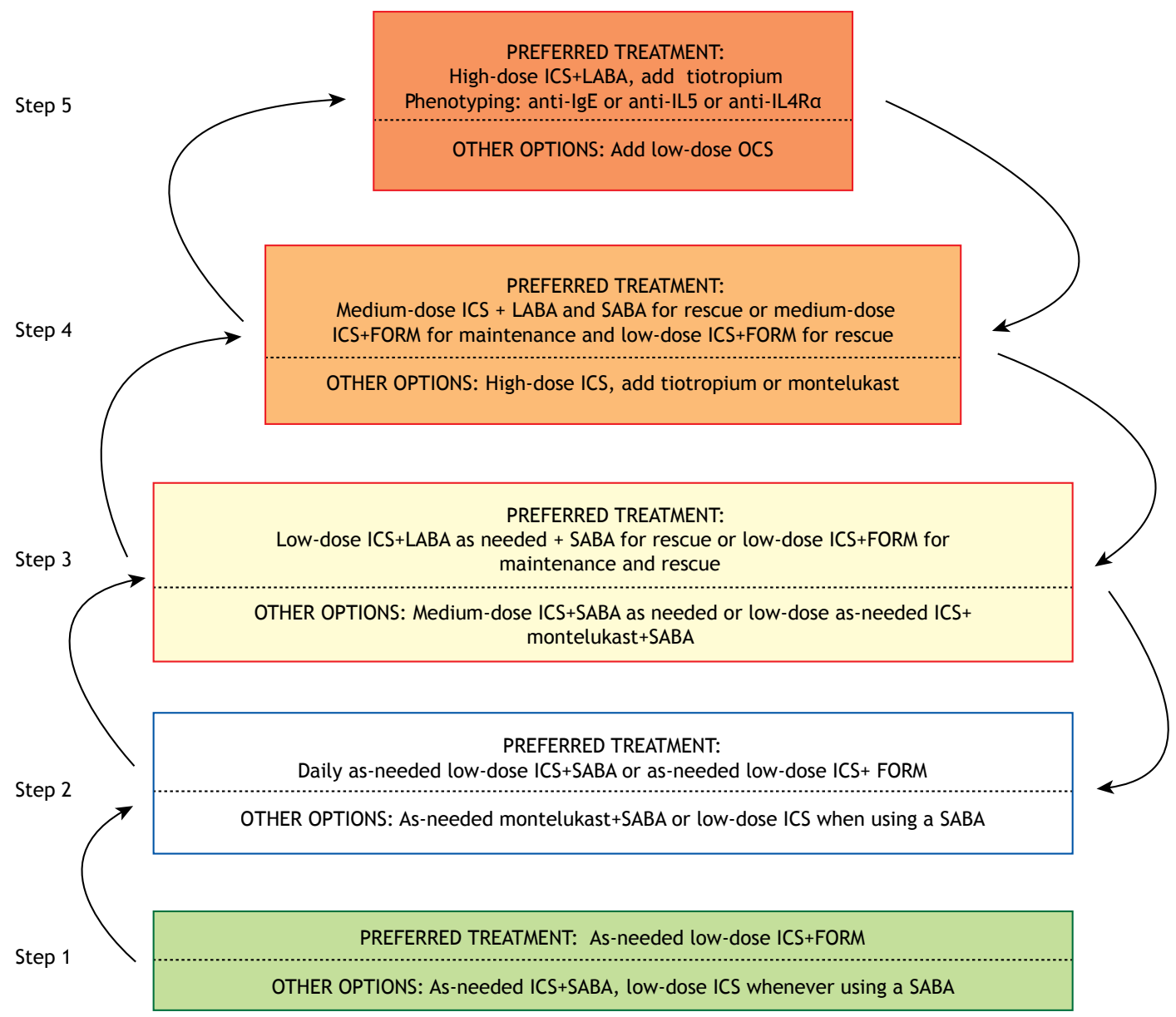

ALL ASTHMA PATIENTS

Environmental control plus regular monitoring of asthma control and future risks

Figure 1. Asthma management for patients $\geq 12$ years of age. ICS: inhaled corticosteroid(s); LABA: long-acting $\beta_{2}$ agonist; OCS: oral corticosteroid(s); SABA: short-acting $\beta_{2}$ agonist; and FORM: formoterol fumarate.

combination compared with those using the same dose of ICS alone showed $16.5 \%{ }^{(45)}$ and $21.0 \%{ }^{(46)}$ fewer severe exacerbations, respectively, in those using the former. This effect was even more pronounced among adolescents, in whom the risk of severe asthma exacerbations was 35\% lower when the ICS-LABA combination was used. ${ }^{(45)}$

The safety of the ICS-LABA combination was tested in multicenter and multinational RCTs in adults ${ }^{(45,46)}$ and children, ${ }^{(47)}$ carried out under the auspices of the US Food and Drug Administration, involving a total of more than 20,000 patients with asthma who were $\geq 12$ years of age and more than 6,000 who were 4-11 years of age. ${ }^{(47)}$ Those studies showed that the budesonide-formoterol and salmeterol-fluticasone combinations do not increase the risk of hospitalization for asthma, the number of asthma-related intubations, or the number of asthma-related deaths in comparison with the use of ICS alone. However, the use of LABA alone in asthma is contraindicated because it increases the risk of asthma-related hospitalization and death. ${ }^{(54)}$ These findings are considered class effects.

\section{Strategy for the use of ICS+LABA: fixed dose or variable dose}

The use of the ICS-LABA combination in asthma treatment can be recommended in a fixed dose with the addition of a SABA as rescue medication or in a variable dose with budesonide+formoterol or beclomethasone+formoterol as controller and rescue medications in a single inhaler. ${ }^{(1)}$ The efficacy of the fixed or variable strategies has been confirmed by several meta-analyses, RCTs, and real-life studies. ${ }^{(40-46,55)}$

To date, there have been no meta-analyses proving the superiority of one strategy over another ${ }^{(44,55)}$, and the GINA therefore recommends the ICS-LABA combination without specifying the strategy (fixed or variable) for the treatment of asthma in steps 3-5.(1) One recent meta-analysis ${ }^{(55)}$ evaluated 64 RCTs (with a collective sample of approximately 60,000 patients) and 


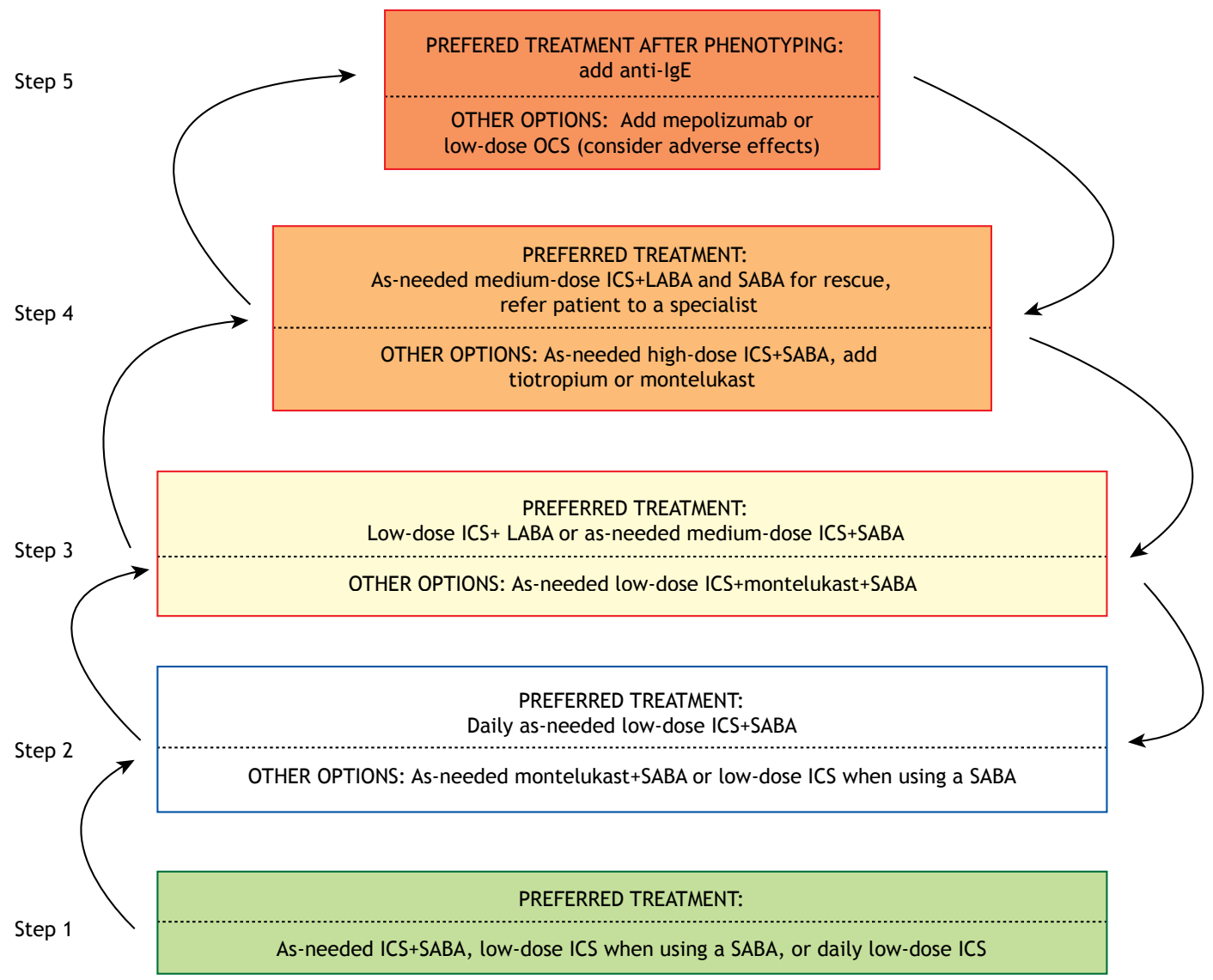

ALL ASTHMATICS

Environmental control plus regular monitoring of asthma control and future risks

Figure 2. Asthma management in children between 6 and 11 years of age. OCS: oral corticosteroid(s); ICS: inhaled corticosteroid(s); LABA: long-acting $\beta_{2}$ agonist; and SABA: short-acting $\beta_{2}$ agonist.

compared the fixed and variable dose strategies with various ICS-LABA combinations. The results showed that, with either strategy, the use of an ICS-LABA combination is more effective for the prevention of severe asthma exacerbations than is the use of an ICS alone. Therefore, the choice of fixed or variable strategies should be determined by the physician, after the characteristics and preferences of the patient have been evaluated.

In the strategy using ICS+formoterol as controller and rescue medication, the dose is adjusted by the patient when there are symptoms. The rationale is that the anti-inflammatory agent functions as a controller medication and the fast-acting LABA functions as a rescue medication. ${ }^{(41,44,55)}$ It is recommended to use a fixed dose, generally once every $12 \mathrm{~h}$, with additional doses, if necessary, up to six times per day (maximum, 12 inhalations/day). In addition, the controller and rescue medication strategy reduces the risk of exacerbations even with the lower doses of ICS employed. ${ }^{(41,44)}$

\section{Control-based asthma management in steps}

Individualizing the treatment of asthma according to the level of control of the disease, the characteristics/ preferences of the patient, and the level of access to treatment ${ }^{(1)}$ requires more frequent consultations (every 3-6 months) and regular monitoring. The rationale for adjusting the asthma treatment is to achieve and maintain control of the disease, as well as to reduce future risks, ${ }^{(1-4,6)}$ with the lowest possible dose of controller medication. Every patient should receive an updated action plan, and the results of the dose adjustment should be monitored, if possible, by objective measures.

The adjustment (increase or decrease) of the dose of controller medication should involve the use of objective tools that indicate the degree of asthma control (Chart 1). If the asthma is not controlled, the medication or dose will be adjusted in accordance with the next step up, whereas it will be adjusted in accordance with the next step down if the asthma is controlled (Figures 1 and 2). 


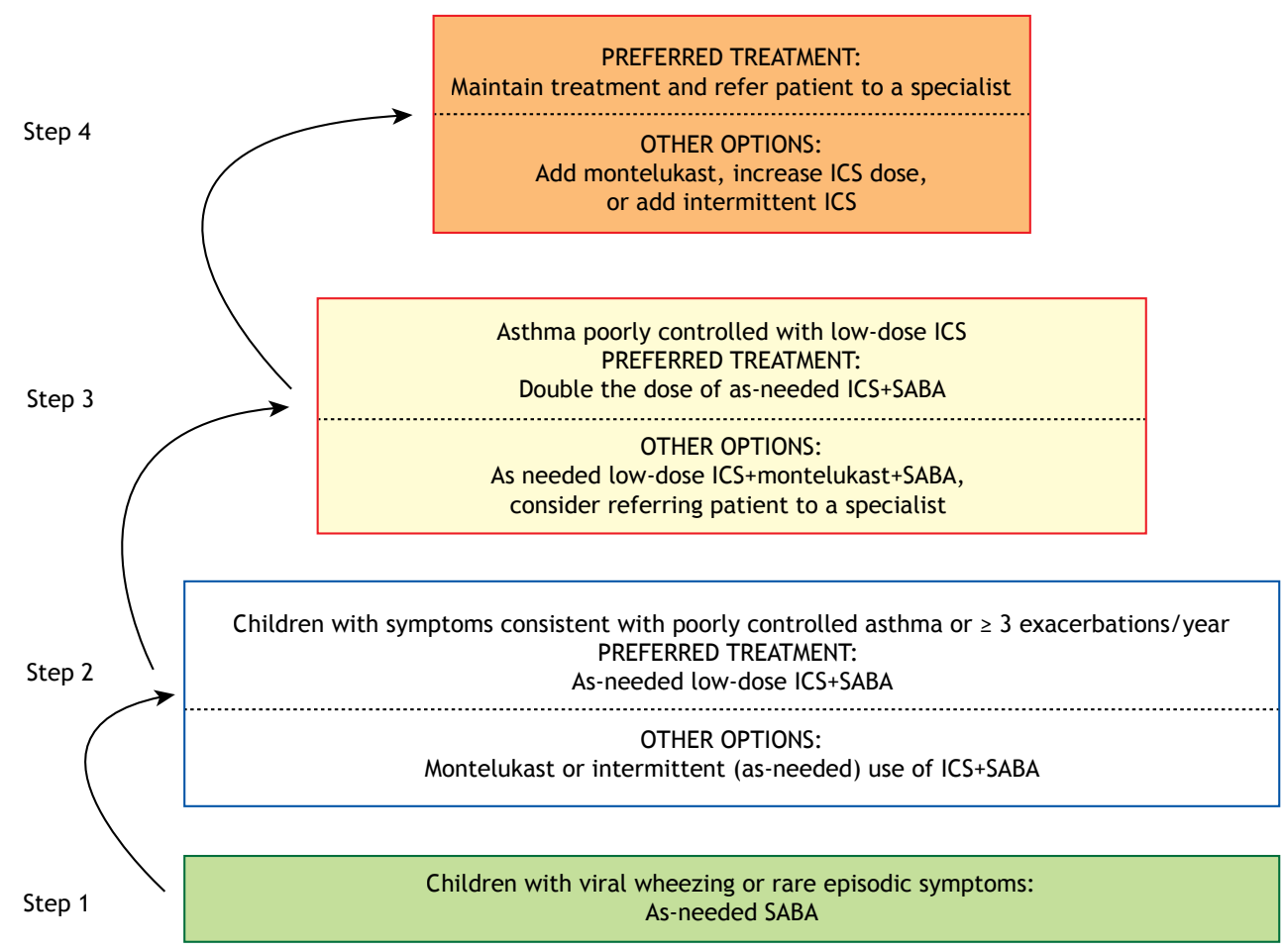

Figure 3. Asthma management for children $\leq 5$ years of age. ICS: inhaled corticosteroid(s); and SABA: short-acting $\beta_{2}$ agonist.

Any strategy to increase or decrease the controller medication dose should be patient-centered, including the assessment of asthma stability (defined as current control and the absence of severe exacerbations in the last year), treatment adherence, the control of comorbidities, the risk of exacerbations, occupational/ environmental exposure, the treatment level, and the potential adverse effects of medication. ${ }^{(1,56)}$ There have been few studies about the optimal timing of a dose reduction. Reducing the dose too soon increases the risk of exacerbations, ${ }^{(1)}$ as does the cessation of ICS use. ${ }^{(56,57)}$

In the fixed-dose strategy, the treatment should be adjusted periodically, increasing or decreasing the dose in accordance with the level of control. For patients using ICS+formoterol for control and rescue, the dose is adjusted by the patient in accordance with the selfperception of symptoms, although the control of the disease and functional changes should be monitored.

A recent meta-analysis ${ }^{(58)}$ evaluating six RCTs involving adults with well-controlled asthma receiving ICS alone and three RCTs with the same type of patients receiving ICS+LABA showed that it is possible to reduce the ICS dose by $50-60 \%$ without increasing the risk of exacerbations. Although the level of evidence of that study was insufficient to determine whether reducing the ICS dose is more beneficial than harmful, dose reduction should be attempted in order to avoid the use of unnecessarily high doses.

Another possibility for adjusting the controller medication would be to eliminate the LABA from the combination, returning to the use of ICS therapy alone. However, a meta-analysis of studies involving adults ${ }^{(59)}$ showed that the elimination of the LABA leads to a reduction in the quality of life and in asthma control. $A$ subanalysis of a recent $\mathrm{RCT}^{(45)}$ comparing the ICS+LABA combination with ICS alone showed that, in patients with asthma that was well controlled with ICS+LABA, the shift to ICS alone significantly increased the risk of exacerbations. Therefore, the withdrawal of the LABA is not recommended for patients in whom asthma is controlled with ICS+LABA.

\section{ALTERNATIVES FOR ASTHMA CONTROL TREATMENT}

As mentioned earlier, the basis of the pharmacological treatment for achieving control and preventing future risks in asthma is the use of an ICS with or without a LABA. However, other medications play an important role, either in the relief of symptoms, such as a SABA, or as an option in the first-line control treatment, and the previous maintenance therapy can even be reintroduced for patients who have not achieved control.

\section{As-needed ICS+SABA}

The use of as-needed ICS+SABA is another option recommended for the control treatment in steps 1 and 2 of the 2019 GINA. ${ }^{(1)}$ This recommendation is based on studies ${ }^{(60-62)}$ of patients in step 2 who used an ICS and a SABA in separate or combined inhalers, which showed that this strategy significantly reduced exacerbations when compared with the use of a SABA 
Table 2. Equivalence of doses of inhaled corticosteroids licensed for use in Brazil. ${ }^{a}$

\begin{tabular}{|c|c|c|c|c|}
\hline \multicolumn{5}{|c|}{ ADULTS AND ADOLESCENTS ( $\geq 12$ years of age) } \\
\hline Corticosteroids & Type of inhaler & Low dose, $\mu \mathrm{g} / \mathrm{day}{ }^{b}$ & Medium dose, $\mu \mathrm{g} / \mathrm{day}$ & $\begin{array}{c}\text { High dose, } \\
\mu \mathrm{g} / \text { day }^{c}\end{array}$ \\
\hline Beclomethasone dipropionate & DPI, HFA & $100-200$ & $>200-400$ & $>400$ \\
\hline Budesonide & DPI, HFA & $200-400$ & $>400-800$ & $>800$ \\
\hline Fluticasone propionate & DPI, HFA & $100-250$ & $>250-500$ & $>500$ \\
\hline Fluticasone Furoate & DPI & na & 100 & 200 \\
\hline Mometasone Furoate & DPI & $110-220$ & $>220-440$ & $>440$ \\
\hline \multicolumn{5}{|c|}{ CHILDREN 6-11 YEARS OF AGE } \\
\hline Corticosteroids & Type of inhaler & Low dose, $\mu \mathrm{g} / \mathrm{day}{ }^{\mathrm{b}}$ & Medium dose, $\mu \mathrm{g} / \mathrm{day}$ & $\begin{array}{c}\text { High dose, } \\
\mu \mathrm{g} / \text { day }^{c}\end{array}$ \\
\hline Beclomethasone dipropionate & DPI, HFA & $50-100$ & $>100-200$ & $>200$ \\
\hline \multirow[t]{2}{*}{ Budesonide } & DPI & $100-200$ & $>200-500$ & $>500$ \\
\hline & Vials & $250-500$ & $>500-1,000$ & $>1,000$ \\
\hline \multirow[t]{2}{*}{ Fluticasone propionate } & HFA & $100-200$ & $>200-500$ & $>500$ \\
\hline & DPI & $100-200$ & $>200-400$ & $>400$ \\
\hline Mometasone Furoate & DPI & 110 & $\geq 220<440$ & $\geq 440$ \\
\hline \multicolumn{5}{|c|}{ CHILDREN < 6 YEARS OF AGE } \\
\hline Corticosteroids & Type of inhaler & Low dose, $\mu \mathrm{g} / \mathrm{day}$ & Age & \\
\hline Beclomethasone dipropionate & HFA & 100 & $\geq 5$ years & \\
\hline Budesonide & Vial & 500 & $\geq 6$ months & \\
\hline Fluticasone propionate & HFA & 50 & $\geq 4$ years & \\
\hline Mometasone Furoate & DPI & 110 & $\geq 4$ years & \\
\hline
\end{tabular}

DPI: dry powder inhaler; HFA: hydrofluoroalkane, pressurized inhaler; and na: not available. aDose labeled on the medication box. 'Standard dose to start and maintain the treatment of most patients. ${ }^{(2,9)}$ cGreatly increases the frequency and intensity of systemic adverse effects.

alone, in addition to reducing the risk of excessive SABA use, given that adherence to the ICS alone is low in this relatively asymptomatic population. In addition, the ICS-SABA combination is available in many countries, including Brazil, and is more affordable than is the ICS-LABA combination.

\section{Montelukast}

Montelukast is a leukotriene receptor antagonist that acts by blocking bronchoconstriction and reducing airway inflammation. Although the effect of montelukast is not inferior to that of an ICS in the control of asthma, ${ }^{(63)}$ it is less effective in reducing the risk of exacerbations. Montelukast combined with an ICS is included as another treatment option in GINA steps 2-4.(1) Montelukast can also be added to the ICS-LABA combination in order to improve asthma control (step 4) and may be an alternative to the use of a SABA in exercise-induced asthma, being used daily or intermittently. ${ }^{(64)}$ The recommended daily dose of montelukast is $4 \mathrm{mg}$ for asthma patients from 2 to 5 years of age, $5 \mathrm{mg}$ for those from 6 to 14 years of age, and $10 \mathrm{mg}$ for those $\geq 15$ years of age. ${ }^{(65,66)}$

\section{SABA AS RESCUE MEDICATION}

In step 1 of the GINA treatment, the use of SABA combined with ICS is an alternative to the use of as-needed low-dose ICS+formoterol. In patients using an ICS alone or fixed-dose ICS+LABA, a SABA is indicated as an optional rescue medication in all of the GINA asthma treatment steps. ${ }^{(1)}$
The as-needed use of a SABA (always combined with ICS) is effective for the immediate relief of symptoms and for the short-term prevention of symptoms induced by exercise. The frequency of the use of a SABA is one of the parameters that define which maintenance therapy is the most appropriate, and the reduction of its usage is one of the goals of the asthma treatment. ${ }^{(1)}$ The excessive use of SABA ( $>3$ canisters/year) is associated with an increased risk of exacerbations, and the use of $>1$ canister/month is associated with a higher risk of death from asthma. ${ }^{(1)}$

\section{ASTHMA MANAGEMENT IN CHILDREN 6-11 YEARS OF AGE}

With the objective of reducing risk and controlling symptoms, the pharmacological treatment for children 6-11 years of age with asthma is basically similar to that employed for adolescent and adult asthma patients (Figure 2). Except for a few studies on the particulars of the safety of corticosteroids, there have been almost no studies on the use of some medications in this age range. As a preferred recommendation in the treatment steps, the main controller medications used (ICS, LABAs, and leukotriene receptor antagonists) are the same for patients $\geq 12$ years of age. In recent years, the treatment alternatives for 6 - to 11 -year-old children with severe asthma have expanded to include omalizumab (an anti-IgE monoclonal antibody), as well as, more recently, tiotropium (an anticholinergic) and mepolizumab (an anti-IL-5 monoclonal antibody). The following are the particular characteristics of 
pharmacological treatment in this age group, considering the GINA treatment steps ${ }^{(1)}$ :

- Step 1: A SABA should be used as needed and combined with an ICS when symptoms occur. ${ }^{(61)}$

- Step 2: The preferred treatment is continuous, low-dose ICS therapy.

- Step 3: The preferred treatment is moderate-dose ICS therapy or low-dose ICS therapy combined with a LABA.

- Step 4: Patients with uncontrolled disease in step 3 should maintain the controller medication and be referred to a specialist, who will evaluate the need to increase the ICS dose or to add tiotropium.

- Step 5: Tiotropium, omalizumab, and mepolizumab are options for this age group, according to the asthma phenotype and the clinical experience of the specialist. After many years as a first option, the use of low-dose oral corticosteroids (OCS) has become the last option for combination at this treatment step.

Of all adverse ICS effects, growth, bone metabolism, and the risk of fractures in children and adolescents have been the main focus of studies in recent years. However, severe uncontrolled asthma can also impair growth, and studies to date have shown that regular ICS use in children causes only a transitory reduction in the growth rate and appears to result in only a slight reduction in their final stature. ${ }^{(67)}$ Osteopenia and the risk of fractures are associated with more frequent use of systemic corticosteroids (oral or injectable). ${ }^{(68,69)}$ Therefore, the benefits of ICS in asthma control outweigh its potential adverse effects on growth.

\section{ASTHMA MANAGEMENT IN CHILDREN < 6 YEARS OF AGE}

A diagnosis of asthma is more likely in children who present cough, recurrent wheezing (during sleep or prompted by triggers such as physical activity, laughing, crying, or exposure to tobacco or pollution), respiratory distress (when exercising, laughing, or crying), or a reduction in physical activity, as well as in those who have a parent with asthma, those who have a history of other allergies (atopic dermatitis or rhinitis), and those in whom the therapeutic test with low-dose ICS is positive (clinical improvement after 2-3 months of treatment and loss of control when the treatment is stopped). ${ }^{(1)}$

\section{Maintenance therapy}

The goal of maintenance therapy is to achieve asthma control, maintaining the normal activity of the child with a minimum of medication. It also seeks to reduce crises, allow healthy lung development, and avoid side effects.

Preventive treatment should be initiated if the clinical presentation is consistent with asthma and the symptoms are uncontrolled. If the diagnosis is uncertain, a SABA should be used as rescue medication. However, if the episodes of wheezing become recurrent, a therapeutic test with low-dose ICS is recommended.
The treatment should be administered via a pressurized, metered-dose inhaler with a spacer and a mask (for children $<4$ years of age), although an inhaler without a mask should be used in older children. Those responsible for the child should be instructed in the correct use of the inhaler and the proper inhalation technique. The dose equivalence of the ICS in this age group is described in Table 2. The treatment should be adjusted in accordance with the level of asthma control (Figure 3).

The response to treatment should be evaluated. In the absence of a response, the treatment should be discontinued and alternative diagnoses should be considered. If satisfactory asthma control is not achieved with moderate-dose ICS combined with montelukast, adding a LABA could be considered. We emphasize that there have been very few studies evaluating the efficacy and safety of the use of this combination in this age group. ${ }^{(47,70,71)}$ In this situation, referring the patient to a specialist should be considered.

\section{Rescue therapy}

Crises should be treated with $200 \mu \mathrm{g}$ of albuterol or equivalent, with the use of a spacer, with or without a mask. The same dose should be administered every $20 \mathrm{~min}$, if necessary. If using more than 6 puffs of albuterol in the first $2 \mathrm{~h}$, ipratropium bromide $(80 \mu \mathrm{g}$, or $250 \mu \mathrm{g}$ by nebulization) can be added every $20 \mathrm{~min}$ to $1 \mathrm{~h}^{(72)}$ In the absence of a satisfactory response, it is recommended that the patient seek prompt medical treatment.

The routine use of OCS during crises is not recommended and should be restricted to crises that require emergency care. In such cases, the physician should prioritize low doses and treatment for the least number of days possible $(1-2 \mathrm{mg} / \mathrm{kg}$ per day of prednisone/prednisolone for 3-5 days, with maximum doses of $20 \mathrm{mg}$ per day for children $\leq 2$ years of age and $30 \mathrm{mg}$ per day for children $>2$ and $\leq 5$ years of age). After emergency consultation, the patient should be reevaluated at $24-48 \mathrm{~h}$ and within $3-4$ weeks thereafter.

\section{MANAGEMENT OF SEVERE ASTHMA}

Severe asthma is defined as that which remains uncontrolled with maximum optimized treatment or that needs this treatment to prevent the disease from becoming uncontrolled (in an attempt to reduce the dose of ICS or OCS), despite the suppression or minimization of factors that impair asthma control. ${ }^{(73,74)}$ The maximum treatment means using high doses of ICS and a second controller medication within the previous year or the use of OCS on $\geq 50 \%$ of the days in the last year. ${ }^{(73)}$

Severe asthma is a subgroup of difficult-to-control asthma. In a recent study, Hekking et al. . $^{(32)}$ estimated that the prevalence of difficult-to-control asthma is $17.4 \%$ but that only $3.6 \%$ of the patients with difficult-to-control asthma have severe asthma. ${ }^{(74)}$ 
Therefore, the diagnosis of severe asthma is made retrospectively. The suppression or minimization of modifiable factors associated with the lack of control is not always possible, which may complicate the diagnosis of severe asthma.

\section{Tiotropium}

Tiotropium bromide, at a dose of $5 \mu \mathrm{g} /$ day, is recommended as adjuvant therapy for patients with asthma aged $>6$ years with uncontrolled asthma in the GINA steps 4 and 5 . $^{(1)} A$ systematic review showed that the combination of tiotropium and IC+LABA improves lung function and reduces the rate of exacerbations. ${ }^{(75)}$

Although there have been no studies comparing the use of tiotropium with that of biologic agents or establishing what the preferred medication would be following the addition of the various controller medications in GINA step 5, for reasons of availability, the use of tiotropium could be recommended over that of a biologic agent. ${ }^{(76)}$ In patients with asthma that is less severe (step 3), tiotropium can be an alternative to the use of LABAs, which can increase the risk of adverse events (when they are not well tolerated by the patients) or can be ineffective. ${ }^{(77)}$ Reports of adverse effects such as dry mouth and urinary retention are typically associated with anticholinergic drugs but are infrequent in patients with asthma. ${ }^{(78)}$

\section{Omalizumab}

Omalizumab is a humanized anti-IgE monoclonal antibody, ${ }^{(79)}$ approved for use in Brazil and recommended in GINA step 5 for the treatment of severe allergic asthma. One review of the literature, ${ }^{\left({ }^{(8)}\right.}$ evaluating 25 RCTs involving patients with moderate to severe allergic asthma, showed that omalizumab, when compared with a placebo, reduced the exacerbations by approximately $25 \%$, decreased the number of hospitalizations, and allowed a slight reduction in the dose of ICS. A systematic review of 42 real-life studies, ${ }^{\left({ }^{(81)}\right.}$ two of which were conducted in Brazil, ${ }^{(82,83)}$ showed that omalizumab improved asthma control, reduced the number of emergency room visits/hospitalizations, and allowed the use of lower doses of OCS and ICS.

Omalizumab is recommended for patients with severe asthma $\geq 6$ years of age. The dose varies depending on patient weight $(20-150 \mathrm{~kg})$ and total serum IgE $(30-1,500 \mathrm{IU} / \mathrm{mL})$ and is administered subcutaneously every 2 or 4 weeks. Response to this treatment has no predictor or single outcome. We recommend evaluating its effectiveness based on clinical outcomes after its use for 16 weeks. ${ }^{(84)}$ It is generally well tolerated. Despite the risk of anaphylaxis being low $(0.07-0.14 \%)$, patients should receive the medication and be monitored in an environment with adequate equipment for cardiopulmonary resuscitation after the administration of each dose. ${ }^{(84)}$

\section{Mepolizumab}

Mepolizumab is a humanized monoclonal antibody that inhibits IL-5 from binding to its receptors in the eosinophils, which consequently reduces eosinophilic inflammation. ${ }^{(85)}$

Several RCTs ${ }^{(86-91)}$ and a meta-analysis( ${ }^{(92)}$ showed that the addition of mepolizumab to the treatment for severe asthma relieves symptoms, improves lung function, reduces exacerbations, has an OCS-sparing effect in asthma patients who are dependent on OCS, and produces a significant, clinically relevant improvement in quality of life.

In Brazil, mepolizumab is recommended for the treatment of severe eosinophilic asthma in patients over the age of 6 years in GINA step 5. ${ }^{(74,91)}$ Studies of mepolizumab have characterized eosinophilia in peripheral blood as $\geq 150$ cells $/ \mu \mathrm{L}$ at the time of evaluation or $\geq 300$ cells $/ \mu \mathrm{L}$ in the last 12 months. ${ }^{(74,91)}$

Mepolizumab should be used subcutaneously at a dose of $100 \mathrm{mg}$ every 4 weeks and rarely causes hypersensitivity reactions.

\section{Benralizumab}

Benralizumab is a humanized IgG1-kappa monoclonal antibody, recommended as an add-on therapy in patients with severe eosinophilic asthma. When it binds to the IL-5 receptor alpha, it leads to apoptosis of eosinophils, resulting in rapid and almost complete depletion of serum levels of eosinophils. ${ }^{(93)}$

Several RCTs ${ }^{(94-97)}$ and one meta-analysis ${ }^{(92)}$ showed that the addition of benralizumab to the usual treatment in GINA step 5 reduces the rate of exacerbations and the need for chronic OCS use, with improvement of symptoms and lung function. Those studies defined severe eosinophilic asthma as $\geq 300$ cells/ $\mu \mathrm{L}$ in the peripheral blood.

In Brazil, benralizumab is recommended for patients above the age of 18 years in GINA step $5^{(1,74)}$ and is available as a single-dose syringe. The recommended dose is $30 \mathrm{mg}$ administered subcutaneously, every 4 weeks for the first three doses, and every 8 weeks thereafter. Benralizumab seldom causes hypersensitivity reactions.

\section{Low-dose OCS}

The use of OCS is recommended as an add-on therapy in patients with severe uncontrolled asthma in GINA step 5. ${ }^{(1,74)}$ Before starting the maintenance OCS, it is essential to review all conditions that can be associated with a lack of response to the asthma treatment: other medications in use, adherence, inhalation technique, comorbidities, and exposures. Its prolonged use can cause severe adverse effects, including growth retardation in children, glaucoma, cataracts, diabetes mellitus, osteoporosis, infections, and blockage of the hypothalamic-pituitary-adrenal axis. $(73,74,98)$

Some strategies, such as the use of OCS at low doses ( $\leq 7.5 \mathrm{mg}$ of prednisolone) or on alternate days, can minimize the risk of adverse effects. After the prolonged use of OCS (for $>3$ months), the patient should be monitored permanently, due to the risk of acute adrenal insufficiency in cases of trauma, acute 
disease, or surgery. In those cases, corticosteroid replacement may be necessary. ${ }^{(1,73,74)}$ The use of low-dose OCS (with or without an antifungal) can also be recommended for the treatment of allergic bronchopulmonary aspergillosis. ${ }^{(74)}$

\section{Azithromycin}

The use of azithromycin for treating asthma is controversial. A systematic review of the literature in 2015 evaluated all clinical trials involving azithromycin and concluded that there was no evidence that its use would be better than a placebo for the majority of clinical outcomes. ${ }^{(99)}$ However, a recent RCT showed improvement of asthma control and reduction of eosinophilic and noneosinophilic asthma exacerbations with the use of oral azithromycin at a dose of $500 \mathrm{mg}$ three times per week for 12 months. ${ }^{(100)}$ In addition, this use of azithromycin is off-label and may be associated with adverse effects such as ototoxicity, cardiac arrhythmia, and increased QT interval, as well as increased drug resistance of bacteria. Further studies are required to prove its efficacy and safety in the control of asthma. ${ }^{(1)}$

\section{Other medications for the treatment of severe asthma}

Dupilumab is a monoclonal antibody against the IL-4 receptor alpha, ${ }^{(101)}$ recommended for the treatment of severe asthma of the Th2-high subtype, characterized by elevated eosinophil counts or fractional exhaled nitric oxide levels, in patients $>12$ years of age. When it binds to the IL-4 receptor, dupilumab also inhibits the activity of IL-13, another important player in this asthma phenotype. Dupilumab reduces asthma exacerbations, allows a gradual reduction in the use of OCS, and improves lung function. ${ }^{(101-105)}$ It is administered subcutaneously, at a recommended dose of $400 \mathrm{mg}$ initially, followed by $200 \mathrm{mg}$ on alternate weeks. For patients using OCS or with comorbidities (atopic dermatitis, nasal polyposis, or eosinophilic esophagitis), the recommended dose is $600 \mathrm{mg}$ initially, followed by $300 \mathrm{mg}$ every 2 weeks. In Brazil, dupilumab is already used for atopic dermatitis and should soon be approved by the Brazilian National Health Oversight Agency for clinical use in asthma.

Reslizumab is an anti-IL-5 monoclonal antibody for the treatment of severe, uncontrolled, eosinophilic asthma (GINA step 5), although it has yet to be approved for clinical use in Brazil.(106) Reslizumab is administered intravenously in adults ( $\geq 18$ years of age) with blood eosinophil counts $>400$ cells $/ \mu \mathrm{L}$ at a dose of $3 \mathrm{mg} / \mathrm{kg}$ of body weight for 25-50 min every 4 weeks, resulting in a reduction of symptoms and exacerbations and an improvement in lung function. ${ }^{(92,106)}$

\section{OTHER APPROACHES TO ASTHMA MANAGEMENT}

\section{Vaccines}

In Brazil, influenza vaccinations are indicated for patients with asthma ${ }^{(107)}$ because the virus is associated with increased morbidity in such patients. ${ }^{(108-110)}$ Two meta-analyses concluded that, although there is evidence that vaccinating these individuals can prevent infection and asthma exacerbations, the quality of the evidence is low. ${ }^{(109,110)}$ There are no contraindications to the vaccination of asthma patients. Those with only mild reactions to eggs (urticaria or angioedema) can be vaccinated at a primary health care clinic. Patients with a history consistent with or suspicious for anaphylactic reactions to eggs should be vaccinated in a setting suitable for the treatment of a possible anaphylactic reaction. ${ }^{(111,112)}$

Asthma patients, especially those with severe asthma, are more susceptible to pneumococcal infections. ${ }^{(113,114)}$ Pneumococcal vaccines (the 23-valent pneumococcal polysaccharide vaccine and the 10-valent pneumococcal conjugate vaccine) are available through the SUS for individuals with persistent moderate or severe asthma, ${ }^{(107)}$ as is the 10-valent pneumococcal conjugate vaccine for children up to 1 year and 11 months of age. The Sociedade Brasileira de Pneumologia e Tisiologia (SBPT, Brazilian Thoracic Association) recommends the sequential use of pneumococcal vaccines: the 13-valent pneumococcal conjugate vaccine followed by the 23 -valent pneumococcal polysaccharide vaccine 6 months later. ${ }^{(115)}$

\section{Immunotherapy}

Immunotherapy administered subcutaneously or sublingually is an option for patients who have asthma with a prominent allergic component. A meta-analysis of 98 studies $^{(116)}$ found that immunotherapy was effective in reducing the symptoms and the need to use controller medication, regardless of patient age and duration of treatment, in individuals with mild-to-moderate asthma who are monosensitized for house dust mites. The benefit is less robust in individuals with severe asthma who are polysensitized. The risk of adverse systemic reactions was found to be higher after subcutaneous administration of immunotherapy in comparison with placebo. Another meta-analysis ${ }^{(117)}$ reported modest benefits of sublingual immunotherapy in patients with mild-to-moderate asthma.

\section{ACTION PLAN}

All asthma patients should have a written action plan. This is an important tool in the treatment of asthma to help patients recognize and adjust the treatment early, whenever control becomes difficult. The action plan should be individualized and developed in partnership with the patient. It involves education to monitor the symptoms, early recognition of an exacerbation, and strategies that will guide the patient for home treatment of crises.

The action plan should be divided into four topics: day-to-day treatment of controlled asthma; when, how, and for how long to use rescue medication and to increase the controller medication dose; when to use an OCS; and when to seek emergency medical 
care. ${ }^{(118)}$ In addition, the action plan should include the definitions of asthma control levels throughout. Monitoring strategies and action plans are effective in the control of asthma. ${ }^{(119)}$

SABA as rescue medication when using an ICS alone or fixed-dose ICS+LABA

The repeated use of SABA for $\geq 2$ consecutive days is a warning sign and indicates the need to reintroduce or reassess and adjust the controller medication. A SABA should not be used in isolation. ${ }^{(1)}$ If the patient is using an ICS alone or fixed-dose ICS+LABA and SABA as rescue medications, the action plan should specify the maximum daily dose of SABA and the number of days it should be used before the patient modifies the treatment or seeks routine or emergency medical care. The action plan should indicate that the recommended dose of SABA is from one to two doses inhaled via a spacer, if needed, and may be repeated every 20-30 min (maximum of three doses).

\section{Increasing the ICS dose when using an ICS alone or fixed-dose ICS+LABA}

The ICS dose can be doubled when asthma symptoms worsen, requiring repeated doses of SABA for 1-2 days. The ICS should be reintroduced for patients who have stopped using it. For patients using an ICS alone, the dose should be doubled. For patients using fixed-dose ICS+LABA, the highest dose of the combination should be used. If the patient is already taking the highest dose of the ICS alone, a LABA should be added. For patients using fixed-dose ICS+LABA, the ICS dose should be increased to the highest dose for this combination. ${ }^{(1,3,4)}$
Increasing the ICS dose when using

\section{ICS+formoterol as maintenance and rescue medications}

For patients using ICS+formoterol as maintenance and rescue medications, the action plan must contain a daily fixed dose every $12 \mathrm{~h}$ and additional doses when there are signs of uncontrolled asthma (up to 6 extra doses of $6 \mu \mathrm{g}$ of formoterol). The maximum recommended dose of formoterol is $72 \mu \mathrm{g} /$ day. ${ }^{(41-44,55)}$

\section{Guidelines for the use of OCS}

The action plan should contain guidelines for when and how to start a course of OCS. A dose of up to 40-50 $\mathrm{mg} /$ day for 5-7 days is recommended for patients with no improvement in asthma control $48 \mathrm{~h}$ after using a SABA, with worsening of lung function, or with a more severe exacerbation. For children, the recommendation is a single dose of $1-2 \mathrm{mg} / \mathrm{kg}$ of body weight per day for 3-5 days. Patients should be advised of the adverse effects of using an OCS. It is unnecessary to reduce the dose of the OCS when the duration of treatment is less than 2 weeks.

\section{FINAL CONSIDERATIONS}

Asthma is a complex, heterogeneous disease associated with high morbidity and high utilization of health resources. The management of asthma has changed considerably in recent years. The SBPT regularly publishes guidelines, standards, and position papers on topics relating to the field. In the present manuscript, prepared by 22 pulmonologists and pediatric pulmonologists, with extensive experience in this area, recommendations for the pharmacological treatment of asthma are made and the latest international guidelines are adapted for use in Brazil.

\section{REFERENCES}

1. Global Initiative for Asthma [homepage on the Internet]. Bethesda: Global Initiative for Asthma; c2019 [cited 2019 Mar 01]. Global Strategy for Asthma Management and Prevention (2019 update). [Adobe Acrobat document, 201p.]. Available from: https://ginasthma.org/wpcontent/uploads/2019/06/GINA-2019-main-report-June-2019-wms.pd

2. Beasley R, Hancox RJ, Harwood M, Perrin K, Poot B, Pilcher J, et al Asthma and Respiratory Foundation NZ adult asthma guidelines: a quick reference guide. N Z Med J. 2016;129(1445):83-102.

3. Healthcare Improvement Scotland [homepage on the Internet] Edinburgh: Scottish Intercollegiate Guidelines Network [cited 2019 Mar 01]. British guideline on the management of asthma. Available from: https://www.sign.ac.uk/sign-158-british-guideline-on-themanagement-of-asthma.html

4. National Asthma Council Australia [homepage on the Internet] Sidney: National Asthma Council Australia; c2019 [cited 2019 May 01]. Australian Asthma Handbook. Available from: https://www. asthmahandbook.org.au/

5. National Institute for Health and Care Excellence [homepage on the Internet]. London: the Institute; c2017 [cited 2019 May 01]. Asthma: diagnosis, monitoring and chronic asthma management. [Adobe Acrobat document, 39p.]. Available from: https://www.nice.org.uk/ guidance/ng80/resources/asthma-diagnosismonitoring-and-chronicasthma-management-pdf-1837687975621

6. FitzGerald JM, Lemiere C, Lougheed MD, Ducharme FM, Dell SD Ramsey $\mathrm{C}$, et al. Recognition and management of severe asthma: A Canadian Thoracic Society position statement. Can J Respir Crit
Care Sleep Med. 2017;1(4):199-221. https://doi.org/10.1080/247453 32.2017.1395250

7. Nathan RA, Thompson PJ, Price D, Fabbri LM, Salvi S, González-Díaz S, et al. Taking Aim at Asthma Around the World: Global Results of the Asthma Insight and Management Survey in the Asia-Pacific Region, Latin America, Europe, Canada, and the United States. J Allergy Clin Immunol Pract. 2015;3(5):734-42.e5. https://doi. org/10.1016/j.jaip.2015.04.013

8. Maspero JF, Jardim JR, Aranda A, Tassinari CP, Gonzalez-Diaz SN Sansores $\mathrm{RH}$, et al. Insights, attitudes, and perceptions about asthma and its treatment: findings from a multinational survey of patients from Latin America. World Allergy Organ J. 2013;6(1):19. https://doi. org/10.1186/1939-4551-6-19

9. Fahy JV. Type 2 inflammation in asthma-present in most, absent in many. Nat Rev Immunol. 2015;15(1):57-65. https://doi.org/10.1038/ nri3786

10. Peters MC, Kerr S, Dunican EM, Woodruff PG, Fajt ML, Levy BD et al. Refractory airway type 2 inflammation in a large subgroup of asthmatic patients treated with inhaled corticosteroids. J Allergy Clin Immunol. 2019;143(1):104-113.e14. https://doi.org/10.1016/j. jaci.2017.12.1009

11. Haldar P, Pavord ID, Shaw DE, Berry MA, Thomas M, Brightling $\mathrm{CE}$, et al. Cluster analysis and clinical asthma phenotypes. Am J Respir Crit Care Med. 2008;178(3):218-224. https://doi.org/10.1164/ rccm.200711-17540C

12. Pearce N, Aït-Khaled N, Beasley R, Mallol J, Keil U, Mitchell E, et 
al. Worldwide trends in the prevalence of asthma symptoms: phase III of the International Study of Asthma and Allergies in Childhood (ISAAC). Thorax. 2007;62(9):758-766. https://doi.org/10.1136/ thx.2006.070169

13. To T, Stanojevic S, Moores G, Gershon AS, Bateman ED, Cruz AA, et al. Global asthma prevalence in adults: findings from the crosssectional world health survey. BMC Public Health. 2012;12:204. https://doi.org/10.1186/1471-2458-12-204

14. Barreto ML, Ribeiro-Silva Rde C, Malta DC, Oliveira-Campos M, Andreazzi MA, Cruz AA. Prevalence of asthma symptoms among adolescents in Brazil: National Adolescent School-based Health Survey (PeNSE 2012). Rev Bras Epidemiol. 2014;17 Suppl 1:106115. https://doi.org/10.1590/1809-4503201400050009

15. Cardoso TA, Roncada C, Silva ERD, Pinto LA, Jones MH, Stein RT, et al. The impact of asthma in Brazil: a longitudinal analysis of data from a Brazilian national database system. J Bras Pneumol. 2017:43(3):163168. https://doi.org/10.1590/s1806-37562016000000352

16. Costa E, Caetano R, Werneck GL, Bregman M, Araújo DV, Rufino R. Estimated cost of asthma in outpatient treatment: a real-world study. Rev Saude Publica. 2018;52:27. https://doi.org/10.11606/ S1518-8787.2018052000153

17. Franco $R$, Nascimento HF, Cruz AA, Santos AC, Souza-Machado $\mathrm{C}$, Ponte EV, et al. The economic impact of severe asthma to low-income families. Allergy. 2009;64(3):478-483. https://doi. org/10.1111/j.1398-9995.2009.01981.x

18. Franco R, Santos AC, do Nascimento HF, Souza-Machado C, Ponte E, Souza-Machado A, et al. Cost-effectiveness analysis of a state funded programme for control of severe asthma. BMC Public Health. 2007;7:82. https://doi.org/10.1186/1471-2458-7-82

19. Cançado JED, Penha M, Gupta S, Li WW, Julian GS, Moreira ES Respira project: Humanistic and economic burden of asthma in Brazil. J Asthma. 2019;56(3):244-251. https://doi.org/10.1080/0277 0903.2018.1445267

20. Souza-Machado C, Souza-Machado A, Franco R, Ponte EV, Barreto $\mathrm{ML}$, Rodrigues LC, et al. Rapid reduction in hospitalisations after an intervention to manage severe asthma. Eur Respir J. 2010:35(3):515 521. https://doi.org/10.1183/09031936.00101009

21. Fontes MJ, Affonso AG, Calazans GM, de Andrade CR, Lasmar LM, Nader CM, et al. Impact of an asthma management program on hospitalizations and emergency department visits. J Pediatr (Rio J). 2011;87(5):412-418. https://doi.org/10.2223/JPED.2129

22. de São José BP, Camargos PA, Bateman ED, Botelho CM, de Seixas Maciel JG, Mancuzo EV, et al. Primary care physicians' ability to diagnose the most prevalent respiratory diseases. Int J Tuberc Lung Dis. 2016;20(10):1392-1398. https://doi.org/10.5588/ijtld.16.0294

23. Martins SM, Salibe-Filho W, Tonioli LP, Pfingesten LE, Braz PD, McDonnell J, et al. Implementation of 'matrix support' (collaborative care) to reduce asthma and COPD referrals and improve primary care management in Brazil: a pilot observational study. NPJ Prim Care Respir Med. 2016;26:16047. https://doi.org/10.1038/ npjpcrm.2016.47

24. Sociedade Brasileira de Pneumologia e Tisiologia. Diretrizes da Sociedade Brasileira de Pneumologia e Tisiologia para o manejo da asma. J Bras Pneumol. 2012:38(Suppl 1):S1-S46.

25. Leite M, Ponte EV, Petroni J, D'Oliveira Júnior A, Pizzichini E, Cruz AA. Evaluation of the asthma control questionnaire validated for use in Brazil. J Bras Pneumol. 2008;34(10):756-763. https://doi. org/10.1590/S1806-37132008001000002

26. Roxo JP, Ponte EV, Ramos DC, Pimentel L, D'Oliveira Júnior A Cruz AA. Portuguese-language version of the Asthma Control Test [Article in Portuguese]. J Bras Pneumol. 2010;36(2):159-166. https:// doi.org/10.1590/S1806-37132010000200002

27. Braido F, Chrystyn H, Baiardini I, Bosnic-Anticevich S, van der Molen T, Dandurand RJ, et al. "Trying, But Failing" - The Role of Inhaler Technique and Mode of Delivery in Respiratory Medication Adherence. J Allergy Clin Immunol Pract. 2016;4(5):823-832. https:// doi.org/10.1016/j.jaip.2016.03.002

28. Bonini M, Usmani OS. Novel methods for device and adherence monitoring in asthma. Curr Opin Pulm Med. 2018;24(1):63-69. https://doi.org/10.1097/MCP.0000000000000439

29. Polosa R, Thomson NC. Smoking and asthma: dangerous liaisons. Eur Respir J. 2013;41(3):716-26. https://doi. org/10.1183/09031936.00073312

30. Le Moual N, Carsin AE, Siroux V, Radon K, Norback D, Torén K, et al. Occupational exposures and uncontrolled adult-onset asthma in the European Community Respiratory Health Survey II. Eur Respir
J. 2014;43(2):374-386. https://doi.org/10.1183/09031936.00034913

31. Chung KF. Diagnosis and Management of Severe Asthma. Semin Respir Crit Care Med. 2018;39(1):91-99. https://doi. org/10.1055/s-0037-1607391

32. Hekking PP, Wener RR, Amelink M, Zwinderman AH, Bouvy ML Bel EH. The prevalence of severe refractory asthma. J Allergy Clin Immunol. 2015;135(4):896-902. https://doi.org/10.1016/j. jaci.2014.08.042

33. Derendorf $H$, Nave R, Drollmann A, Cerasoli F, Wurst W. Relevance of pharmacokinetics and pharmacodynamics of inhaled corticosteroids to asthma. Eur Respir J. 2006;28(5):1042-1050. https://doi.org/10.1183/09031936.00074905

34. Daley-Yates PT. Inhaled corticosteroids: potency, dose equivalence and therapeutic index. Br J Clin Pharmacol. 2015;80(3):372-380. https://doi.org/10.1111/bcp.12637

35. Roland NJ, Bhalla RK, Earis J. The local side effects of inhaled corticosteroids: current understanding and review of the literature. Chest. 2004;126(1):213-219. https://doi.org/10.1378/ chest.126.1.213

36. Lipworth BJ. Systemic adverse effects of inhaled corticosteroid therapy: A systematic review and meta-analysis. Arch Intern Med. 1999;159(9):941-955. https://doi.org/10.1001/archinte.159.9.941

37. Lapi F, Kezouh A, Suissa S, Ernst P. The use of inhaled corticosteroids and the risk of adrenal insufficiency. Eur Respir J. 2013;42(1):79-86. https://doi.org/10.1183/09031936.00080912

38. Weatherall M, James K, Clay J, Perrin K, Masoli M, Wijesinghe M et al. Dose-response relationship for risk of non-vertebral fracture with inhaled corticosteroids. Clin Exp Allergy. 2008;38(9):1451-1458. https://doi.org/10.1111/j.1365-2222.2008.03029.x

39. Ye $\mathrm{Q}, \mathrm{He} X, D^{\prime}$ Urzo $A$. A review on the safety and efficacy of inhaled corticosteroids in management of asthma. Pulm Ther. 2017;3(1):1 18. https://doi.org/10.1007/s41030-017-0043-5

40. Greening AP, Ind PW, Northfield M, Shaw G. Added salmeterol versus higher-dose corticosteroid in asthma patients with symptoms on existing inhaled corticosteroid. Allen \& Hanburys Limited UK Study Group. Lancet. 1994;344(8917):219-224. https://doi. org/10.1016/S0140-6736(94)92996-3

41. Pauwels RA, Löfdahl CG, Postma DS, Tattersfield AE, O'Byrne $P$, Barnes PJ, et al. Effect of inhaled formoterol and budesonide on exacerbations of asthma. Formoterol and Corticosteroids Establishing Therapy (FACET) International Study Group [published correction appears in N Engl J Med 1998 Jan 8;338(2):139]. N Engl J Med. 1997;337(20):1405-1411. https://doi.org/10.1056/ NEJM199711133372001

42. Bateman ED, Boushey HA, Bousquet J, Busse WW, Clark TJ Pauwels RA, et al. Can guideline-defined asthma control be achieved? The Gaining Optimal Asthma ControL study. Am J Respir Crit Care Med. 2004:170(8):836-844. https://doi.org/10.1164/ rccm.200401-0330C

43. Bateman ED, Busse W, Pedersen SE, Bousquet J, Huang S, Zhou X et al. Global Initiative for Asthma 2016-derived asthma control with fluticasone propionate and salmeterol: A Gaining Optimal Asthma Control (GOAL) study reanalysis [published correction appears in Ann Allergy Asthma Immunol. 2019 Oct;123(4):418]. Ann Allergy Asthma Immunol. 2019;123(1):57-63.e2. https://doi.org/10.1016/j. anai.2019.04.018

44. Kew KM, Karner C, Mindus SM, Ferrara G. Combination formotero and budesonide as maintenance and reliever therapy versus combination inhaler maintenance for chronic asthma in adults and children. Cochrane Database Syst Rev. 2013;(12):CD009019. https:// doi.org/10.1002/14651858.CD009019.pub2

45. Stempel DA, Raphiou IH, Kral KM, Yeakey AM, Emmett AH, Prazma $\mathrm{CM}$, et al. Serious Asthma Events with Fluticasone plus Salmetero versus Fluticasone Alone. N Engl J Med. 2016;374(19):1822-1830. https://doi.org/10.1056/NEJMoa1511049

46. Peters SP, Bleecker ER, Canonica GW, Park YB, Ramirez R, Hollis S et al. Serious Asthma Events with Budesonide plus Formoterol vs. Budesonide Alone. N Engl J Med. 2016;375(9):850-860. https://doi. org/10.1056/NEJMoa1511190

47. Stempel DA, Szefler SJ, Pedersen S, Zeiger RS, Yeakey AM, Lee LA, et al. Safety of Adding Salmeterol to Fluticasone Propionate in Children with Asthma. N Engl J Med. 2016;375(9):840-849. https:// doi.org/10.1056/NEJMoa1606356

48. Sobieraj DM, Weeda ER, Nguyen E, Coleman Cl, White CM, Lazarus SC, et al. Association of Inhaled Corticosteroids and LongActing $\beta$-Agonists as Controller and Quick Relief Therapy With 
Exacerbations and Symptom Control in Persistent Asthma: A Systematic Review and Meta-analysis. JAMA. 2018;319(14):14851496. https://doi.org/10.1001/jama.2018.2769

49. O'Byrne PM, FitzGerald JM, Bateman ED, Barnes PJ, Zhong N Keen C, et al. Inhaled Combined Budesonide-Formoterol as Needed in Mild Asthma. N Engl J Med. 2018;378(20):1865-1876. https://doi. org/10.1056/NEJMoa1715274

50. Bateman ED, Reddel HK, FitzGerald JM. As-Needed BudesonideFormoterol in Mild Asthma. N Engl J Med. 2018;379(9):898. https:// doi.org/10.1056/NEJMc1808073

51. Beasley R, Holliday M, Reddel HK, Braithwaite I, Ebmeier S, Hancox RJ, et al. Controlled Trial of Budesonide-Formoterol as Needed for Mild Asthma. N Engl J Med. 2019;380(21):2020-2030. https://doi. org/10.1056/NEJMoa1901963

52. Barnes PJ. Scientific rationale for inhaled combination therapy with long-acting beta2-agonists and corticosteroids. Eur Respir $\mathrm{J}$ 2002;19(1):182-191. https://doi.org/10.1183/09031936.02.00283202

53. Bateman ED, Reddel HK, O'Byrne PM, Barnes PJ, Zhong N, Keen C, et al. As-Needed Budesonide-Formoterol versus Maintenance Budesonide in Mild Asthma. N Engl J Med. 2018;378(20):1877-1887. https://doi.org/10.1056/NEJMoa1715275

54. Martinez FD. Safety of long-acting beta-agonists-an urgent need to clear the air. N Engl J Med. 2005;353(25):2637-2639. https://doi. org/10.1056/NEJMp058299

55. Loymans RJ, Gemperli A, Cohen J, Rubinstein SM, Sterk PJ, Reddel $H K$, et al. Comparative effectiveness of long term drug treatment strategies to prevent asthma exacerbations: network meta-analysis. BMJ. 2014;348:g3009. https://doi.org/10.1136/bmj.g3009

56. Rank MA, Hagan JB, Park MA, Podjasek JC, Samant SA, Volcheck $\mathrm{GW}$, et al. The risk of asthma exacerbation after stopping low-dose inhaled corticosteroids: a systematic review and meta-analysis of randomized controlled trials. J Allergy Clin Immunol. 2013;131(3):724 729. https://doi.org/10.1016/j.jaci.2012.11.038

57. Koskela HO, Purokivi MK, Kokkarinen J. Stepping down from combination asthma therapy: The predictors of outcome. Respir Med. 2016;117:109-115. https://doi.org/10.1016/j.rmed.2016.06.010

58. Crossingham I, Evans DJ, Halcovitch NR, Marsden PA. Stepping down the dose of inhaled corticosteroids for adults with asthma. Cochrane Database Syst Rev. 2017;2(2):CD011802. https://doi org/10.1002/14651858.CD011802.pub2

59. Ahmad S, Kew KM, Normansell R. Stopping long-acting beta2agonists (LABA) for adults with asthma well controlled by LABA and inhaled corticosteroids. Cochrane Database Syst Rev. 2015;(6):CD011306. https://doi.org/10.1002/14651858.CD011306 pub2

60. Papi A, Canonica GW, Maestrelli P, Paggiaro P, Olivieri D, Pozzi E, et al. Rescue use of beclomethasone and albuterol in a single inhale for mild asthma. N Engl J Med. 2007;356(20):2040-2052. https://doi. org/10.1056/NEJMoa063861

61. Martinez FD, Chinchilli VM, Morgan WJ, Boehmer SJ, Lemanske $\mathrm{Jr}$ RF, Mauger DT, et al. Use of beclomethasone dipropionate as rescue treatment for children with mild persistent asthma (TREXA): a randomised, double-blind, placebo-controlled trial. Lancet. 2011;377(9766):650-657. https://doi.org/10.1016/S01406736(10)62145-9

62. Calhoun WJ, Ameredes BT, King TS, Icitovic N, Bleecker ER, Castro $\mathrm{M}$, et al. Comparison of physician-, biomarker-, and symptom-based strategies for adjustment of inhaled corticosteroid therapy in adults with asthma: the BASALT randomized controlled trial. JAMA. 2012;308(10):987-997. https://doi.org/10.1001/2012.jama.10893

63. Papi A, Brightling C, Pedersen SE, Reddel HK. Asthma. Lancet 2018:391(10122):783-800. https://doi.org/10.1016/S01406736(17)33311-1

64. Pearlman DS, van Adelsberg J, Philip G, Tilles SA, Busse W, Hendeles $L$, et al. Onset and duration of protection against exerciseinduced bronchoconstriction by a single oral dose of montelukast. Ann Allergy Asthma Immunol. 2006;97(1):98-104. https://doi org/10.1016/S1081-1206(10)61377-4

65. Benard B, Bastien V, Vinet B, Yang R, Krajinovic M, Ducharme FM Neuropsychiatric adverse drug reactions in children initiated on montelukast in real-life practice. Eur Respir J. 2017;50(2):1700148. https://doi.org/10.1183/13993003.00148-2017

66. Glockler-Lauf SD, Finkelstein $Y$, Zhu J, Feldman LY, To T. Montelukast and Neuropsychiatric Events in Children with Asthma: A Nested Case-Control Study. J Pediatr. 2019;209:176-182.e4. https://doi.org/10.1016/.jpeds.2019.02.009
67. Zhang $L$, Lasmar LB, Castro-Rodriguez JA. The impact of asthma and its treatment on growth: an evidence-based review. J Pediatr (Rio J). 2019;95 Suppl 1:10-22. https://doi.org/10.1016/j.jped.2018.10.005

68. Kelly HW, Van Natta ML, Covar RA, Tonascia J, Green RP, Strunk $\mathrm{RC}$, et al. Effect of long-term corticosteroid use on bone minera density in children: a prospective longitudinal assessment in the childhood Asthma Management Program (CAMP) study. Pediatrics. 2008;122(1):e53-e61. https://doi.org/10.1542/peds.2007-3381

69. Gray N, Howard A, Zhu J, Feldman LY, To T. Association Between Inhaled Corticosteroid Use and Bone Fracture in Children With Asthma. JAMA Pediatr. 2018;172(1):57-64. https://doi.org/10.1001/ jamapediatrics.2017.3579

70. Yoshihara S, Tsubaki T, Ikeda M, Lenney W, Tomiak R, Hattori T, et al. The efficacy and safety of fluticasone/salmeterol compared to fluticasone in children younger than four years of age. Pediatr Allergy Immunol. 2019;30(2):195-203. https://doi.org/10.1111/pai.13010

71. Płoszczuk A, Bosheva M, Spooner K, Mclver T, Dissanayake S Efficacy and safety of fluticasone propionate/formoterol fumarate in pediatric asthma patients: a randomized controlled trial. Ther Adv Respir Dis. 2018;12:1753466618777924. https://doi. org/10.1177/1753466618777924

72. Pollock M, Sinha IP, Hartling L, Rowe BH, Schreiber S, Fernandes RM. Inhaled short-acting bronchodilators for managing emergency childhood asthma: an overview of reviews. Allergy. 2017;72(2):183200. https://doi.org/10.1111/all.13039

73. Chung KF, Wenzel SE, Brozek JL, Bush A, Castro M, Sterk PJ, et al. International ERS/ATS guidelines on definition, evaluation and treatment of severe asthma [published correction appears in Eur Respir J. 2014 Apr;43(4):1216. Dosage error in article text] [published correction appears in Eur Respir J. 2018 Jul 27:52(1):]. Eur Respir J. 2014;43(2):343-373.

74. Global Initiative for Asthma [homepage on the Internet]. Bethesda: Global Initiative for Asthma; c2019 [cited 2019 Aug 01]. Difficult-totreat \& Severe Asthma in Adolescent and Adult Patients: Diagnosis and Management. V2.0. [Adobe Acrobat document, 22p.]. Available from: https://ginasthma.org/wp-content/uploads/2019/04/GINASevere-asthma-Pocket-Guide-v2.0-wms-1.pdf

75. Kew KM, Dahri K. Long-acting muscarinic antagonists (LAMA) added to combination long-acting beta2-agonists and inhaled corticosteroids (LABA/ICS) versus LABA/ICS for adults with asthma. Cochrane Database Syst Rev. 2016;(1):CD011721. https://doi. org/10.1002/14651858.CD011721.pub2

76. Israel E, Reddel HK. Severe and Difficult-to-Treat Asthma in Adults. N Engl J Med. 2017;377(10):965-976. https://doi.org/10.1056/ NEJMra1608969

77. Busse WW, Dahl R, Jenkins C, Cruz AA. Long-acting muscarinic antagonists: a potential add-on therapy in the treatment of asthma?. Eur Respir Rev. 2016;25(139):54-64. https://doi. org/10.1183/16000617.0052-2015

78. Dusser D, Ducharme FM. Safety of tiotropium in patients with asthma. Ther Adv Respir Dis. 2019:13:1753466618824010. https:// doi.org/10.1177/1753466618824010

79. McCracken JL, Tripple JW, Calhoun WJ. Biologic therapy in the management of asthma. Curr Opin Allergy Clin Immunol. 2016;16(4):375-382. https://doi.org/10.1097/ACl.0000000000000284

80. Normansell R, Walker S, Milan SJ, Walters EH, Nair P. Omalizumab for asthma in adults and children. Cochrane Database Syst Rev. 2014;(1):CD003559. https://doi.org/10.1002/14651858.CD003559. pub4

81. MacDonald KM, Kavati A, Ortiz B, Alhossan A, Lee CS, Abraham I. Short- and long-term real-world effectiveness of omalizumab in severe allergic asthma: systematic review of 42 studies published 2008-2018. Expert Rev Clin Immunol. 2019;15(5):553-569. https:// doi.org/10.1080/1744666X.2019.1574571

82. Rubin AS, Souza-Machado A, Andradre-Lima M, Ferreira F, Honda A, Matozo TM, et al. Effect of omalizumab as add-on therapy on asthma-related quality of life in severe allergic asthma: a Brazilian study (QUALITX). J Asthma. 2012;49(3):288-293. https://doi.org/10.3 109/02770903.2012.660297

83. Carvalho-Pinto RM, Agondi RC, Giavina-Bianchi P, Cukier A Stelmach R. Omalizumab in patients with severe uncontrolled asthma: well-defined eligibility criteria to promote asthma control. J Bras Pneumol. 2017;43(6):487-489. https://doi.org/10.1590/s180637562017000000012

84. Humbert M, Busse W, Hanania NA, Lowe PJ, Canvin J, Erpenbeck VJ, et al. Omalizumab in asthma: an update on recent developments. J Allergy Clin Immunol Pract. 2014;2(5):525-36.e1. https://doi. 
org/10.1016/j.jaip.2014.03.010

85. Walsh GM. An update on biologic-based therapy in asthma. Immunotherapy. 2013;5(11):1255-1264. https://doi.org/10.2217/ imt.13.118

86. Haldar P, Brightling CE, Hargadon B, Gupta S, Monteiro W, Sousa A, et al. Mepolizumab and exacerbations of refractory eosinophilic asthma [published correction appears in N Engl J Med. 2011 Feb 10;364(6):588]. N Engl J Med. 2009;360(10):973-984. https://doi. org/10.1056/NEJMoa0808991

87. Nair $P$, Pizzichini $M M$, Kjarsgaard $M$, Inman MD, Efthimiadis $A$, Pizzichini $E$, et al. Mepolizumab for prednisone-dependent asthma with sputum eosinophilia. N Engl J Med. 2009;360(10):985-993. https://doi.org/10.1056/NEJMoa0805435

88. Pavord ID, Korn S, Howarth P, Bleecker ER, Buhl R, Keene ON, et al. Mepolizumab for severe eosinophilic asthma (DREAM): a multicentre, double-blind, placebo-controlled trial. Lancet. 2012;380(9842):651 659. https://doi.org/10.1016/S0140-6736(12)60988-X

89. Bel EH, Wenzel SE, Thompson PJ, Prazma CM, Keene ON, Yancey $\mathrm{SW}$, et al. Oral glucocorticoid-sparing effect of mepolizumab in eosinophilic asthma. N Engl J Med. 2014;371(13):1189-1197. https:// doi.org/10.1056/NEJMoa1403291

90. Ortega HG, Liu MC, Pavord ID, Brusselle GG, FitzGerald JM, Chetta A, et al. Mepolizumab treatment in patients with severe eosinophilic asthma [published correction appears in N Engl J Med. 2015 Apr 30;372(18):1777]. N Engl J Med. 2014;371(13):1198-1207. https:// doi.org/10.1056/NEJMoa1403290

91. Chupp GL, Bradford ES, Albers FC, Bratton DJ, Wang-Jairaj J, Nelsen LM, et al. Efficacy of mepolizumab add-on therapy on health-related quality of life and markers of asthma control in severe eosinophilic asthma (MUSCA): a randomised, double-blind, placebo-controlled, parallel-group, multicentre, phase $3 \mathrm{~b}$ trial. Lancet Respir Med. 2017;5(5):390-400. https://doi.org/10.1016/S2213-2600(17)30125-X

92. Farne HA, Wilson A, Powell C, Bax L, Milan SJ. Anti-IL5 therapies for asthma. Cochrane Database Syst Rev. 2017;9(9):CD010834. https:// doi.org/10.1002/14651858.CD010834.pub3

93. Pham TH, Damera G. Newbold P. Ranade K. Reductions in eosinophi biomarkers by benralizumab in patients with asthma. Respir Med. 2016;111:21-29. https://doi.org/10.1016/..rmed.2016.01.003

94. Bleecker ER, FitzGerald JM, Chanez P, Papi A, Weinstein SF, Barker $P$, et al. Efficacy and safety of benralizumab for patients with severe asthma uncontrolled with high-dosage inhaled corticosteroids and long-acting $\beta 2$-agonists (SIROCCO): a randomised, multicentre, placebo-controlled phase 3 trial. Lancet. 2016;388(10056):2115 2127. https://doi.org/10.1016/S0140-6736(16)31324-1

95. FitzGerald JM, Bleecker ER, Nair P, Korn S, Ohta K, Lommatzsch $M$, et al. Benralizumab, an anti-interleukin-5 receptor a monoclonal antibody, as add-on treatment for patients with severe, uncontrolled, eosinophilic asthma (CALIMA): a randomised, double-blind, placebocontrolled phase 3 trial. Lancet. 2016;388(10056):2128-2141. https:// doi.org/10.1016/S0140-6736(16)31322-8

96. Nair P, Wenzel S, Rabe KF, Bourdin A, Lugogo NL, Kuna P, et al. Oral Glucocorticoid-Sparing Effect of Benralizumab in Severe Asthma. N Engl J Med. 2017;376(25):2448-2458. https://doi.org/10.1056/ NEJMoa1703501

97. Busse WW, Bleecker ER, FitzGerald JM, Ferguson GT, Barker P, Sproule $\mathrm{S}$, et al. Long-term safety and efficacy of benralizumab in patients with severe, uncontrolled asthma: 1-year results from the BORA phase 3 extension trial [published correction appears in Lancet Respir Med. 2019 Jan; 7(1):e1]. Lancet Respir Med. 2019;7(1):46-59. https://doi.org/10.1016/S2213-2600(18)30406-5

98. Grossman JM, Gordon R, Ranganath VK, Deal C, Caplan L, Chen W, et al. American College of Rheumatology 2010 recommendations for the prevention and treatment of glucocorticoid-induced osteoporosis [published correction appears in Arthritis Care Res (Hoboken). 2012 Mar:64(3):464]. Arthritis Care Res (Hoboken). 2010;62(11):1515 1526. https://doi.org/10.1002/acr.20295

99. Kew KM, Undela K, Kotortsi I, Ferrara G. Macrolides for chronic asthma. Cochrane Database Syst Rev. 2015;(9):CD002997. https:// doi.org/10.1002/14651858.CD002997.pub4

100. Gibson PG, Yang IA, Upham JW, Reynolds PN, Hodge S, James $\mathrm{AL}$, et al. Effect of azithromycin on asthma exacerbations and quality of life in adults with persistent uncontrolled asthma (AMAZES): a randomised, double-blind, placebo-controlled trial. Lancet. 2017;390(10095):659-668. https://doi.org/10.1016/S01406736(17)31281-3

101. Wenzel S, Ford L, Pearlman D, Spector S, Sher L, Skobieranda F, et al. Dupilumab in persistent asthma with elevated eosinophil levels.
N Engl J Med. 2013;368(26):2455-2466. https://doi.org/10.1056/ NEJMoa1304048

102. Wenzel S, Castro M, Corren J, Maspero J, Wang L, Zhang B, et al. Dupilumab efficacy and safety in adults with uncontrolled persistent asthma despite use of medium-to-high-dose inhaled corticosteroids plus a long-acting $\beta 2$ agonist: a randomised double-blind placebo-controlled pivotal phase $2 \mathrm{~b}$ dose-ranging trial. Lancet. 2016;388(10039):31-44. https://doi.org/10.1016/S01406736(16)30307-5

103. Castro M, Corren J, Pavord ID, Maspero J, Wenzel S, Rabe KF, et al. Efficacy and Safety in Moderate-to-Severe Uncontrolled Asthma. N Engl J Med. 2018;378(26):2486-2496. https://doi.org/10.1056/ NEJMoa1804092

104. Rabe KF, Nair P, Brusselle G, Maspero JF, Castro M, Sher L, et al. Efficacy and Safety of Dupilumab in Glucocorticoid-Dependent Severe Asthma. N Engl J Med. 2018;378(26):2475-2485. https://doi. org/10.1056/NEJMoa1804093

105. Weinstein SF, Katial R, Jayawardena S, Pirozzi G, Staudinger $H$, Eckert $L$, et al. Efficacy and safety of dupilumab in perennia allergic rhinitis and comorbid asthma. J Allergy Clin Immunol. 2018;142(1):171-177.e1. https://doi.org/10.1016/j.jaci.2017.11.051

106. National Institute for Health and Care Excellence (NICE) [homepage on the Internet]. London:. NICE; c2019 [updated 2017 Oct 4; cited 2019 Apr 12]. Reslizumab for treating severe eosinophilic asthma. Available from: https://www.nice.org.uk/guidance/ta479

107. Brasil. Ministério da Saúde. Secretaria de Vigilância em Saúde. Manual dos Centros de Referência para Imunobiológicos Especiais. 4th Ed. Brasília: Ministério da Saúde; 2014. 160p.

108. Skarbinski J, Jain S, Bramley A, Lee EJ, Huang J, Kirschke D, et al. Hospitalized patients with 2009 pandemic influenza A (H1N1) virus infection in the United States-September-October 2009. Clin Infect Dis. 2011;52 Suppl 1:S50-S59. https://doi.org/10.1093/cid/ciq021

109. Vasileiou E, Sheikh A, Butler C, El Ferkh K, von Wissmann B, McMenamin $J$, et al. Effectiveness of Influenza Vaccines in Asthma: A Systematic Review and Meta-Analysis. Clin Infect Dis. 2017;65(8):1388-1395. https://doi.org/10.1093/cid/cix524

110. Cates CJ, Rowe BH. Vaccines for preventing influenza in people with asthma. Cochrane Database Syst Rev. 2013;(2):CD000364. https://doi.org/10.1002/14651858.CD000364.pub4

111. Associação Brasileira de Alergia e Imunologia (ASBAI) [homepage on the Internet] São Paulo: ASBAl; [updated 2016 Apr 16; cited 2019 Mar 20]. Parecer técnico ASBAI e SBIm sobre a Vacina Influenza em pacientes alérgicos a ovo. Available from: http://asbai.org.br/ parecer-tecnico-asbai-e-sbim-sobre-a-vacina-influenza-em-pacientesalergicos-a-ovo/

112. Centers for Disease Control and Prevention [homepage on the Internet].Atlanta: CDC [cited 2019 Aug 18]. Flu Vaccine and People with Egg Allergies. Available from: https://www.cdc.gov/flu/prevent/ egg allergies.htm

113. Klemets $P$, Lyytikäinen $O$, Ruutu $P$, Ollgren J, Kaijalainen $T$, Leinonen $\mathrm{M}$, et al. Risk of invasive pneumococcal infections among working age adults with asthma. Thorax. 2010;65(8):698-702. https:// doi.org/10.1136/thx.2009.132670

114. Inghammar M, Engström G, Kahlmeter G, Ljungberg B, Löfdahl CG, Egesten A. Invasive pneumococcal disease in patients with an underlying pulmonary disorder. Clin Microbiol Infect. 2013;19(12):1148-1154. https://doi.org/10.1111/1469-0691.12182

115. Sociedade Brasileira de Imunizações (SBIM) [homepage on the Internet]. São Paulo: SBIM; c2019 [updated 2018 Sep 3; cited 2019 Mar 23]. Guia de Imunização - Pneumologia 2018-2019. Available from: https://sbim.org.br/publicacoes/guias/73-guia-de-imunizacaopneumologia

116. Dhami S, Kakourou A, Asamoah F, Agache I, Lau S, Jutel M, et al. Allergen immunotherapy for allergic asthma: A systematic review and meta-analysis. Allergy. 2017;72(12):1825-1848. https://doi. org/10.1111/all.13208

117. Blanco $C$, Bazire R, Argiz L, Hernández-Peña J. Sublingual allergen immunotherapy for respiratory allergy: a systematic review. Drugs Context. 2018;7:212552. https://doi.org/10.7573/dic.212552

118. Gibson PG, Powell H. Written action plans for asthma: an evidencebased review of the key components. Thorax. 2004;59(2):94-99. https://doi.org/10.1136/thorax.2003.011858

119. Gupta S, Price C, Agarwal G, Chan D, Goel S, Boulet LP, et al. Electronic Asthma Management System (eAMS) improves primary care asthma management. Eur Respir J. 2019:53(4):1802241. https://doi.org/10.1183/13993003.02241-2018 